\title{
GLAZING DAYLIGHTING PERFORMANCE AND TROMBE WALL THERMAL PERFORMANCE OF A MODULAR FAÇADE SYSTEM IN FOUR DIFFERENT PORTUGUESE CITIES
}

\author{
Helenice M. Sacht' ${ }^{1}$, Luis Bragança², Manuela Almeida ${ }^{3}$, Rosana Caram
}

\begin{abstract}
${ }^{1}$ PhD Student, Centre for Territory, Environment and Construction (C-TAC), Department of Civil Engineering, University of Minho, Guimarães, Portugal, hmsacht@civil.uminho.pt

${ }^{2}$ Coordinator of the Sustainable Building Group, Centre for Territory, Environment and Construction (C-TAC), Associate Professor at the Department of Civil Engineering, University of Minho, Guimarães, Portugal, braganca@civil.uminho.pt

${ }^{3}$ Deputy Director of the Centre for Territory, Environment and Construction (C-TAC), Associate Professor at the Department of Civil Engineering, University of Minho, Guimarães, Portugal, malmeida@civil.uminho.pt

${ }^{4}$ Coordinator of the Architecture, Technology and Materials Group (Arqtema), Associate Professor at the Institute of Architecture and Urbanism, University of São Paulo, São Carlos, Brazil, rcaram@sc.usp.br
\end{abstract}

\begin{abstract}
This paper reports on a new façade system that uses passive solutions in the search for energy efficiency. The differentials are the versatility and flexibility of the modules, which are important advantages of the system. The thermal performance of Trombe walls and glazings and the daylighting performance of glazing were the key aspects analyzed in the results. Computational simulations were accomplished for the thermal performance of different arrangements of the modules with DesignBuilder software. The glazing daylighting performance was studied by means of Ecotect and Desktop Radiance programs and compared with the transmittance curves of glazings. Occupancy profile and internal gains were fixed according to the Portuguese reality for both studies. The main characteristics considered in this research were the use of two double glazings, four different climates in Portugal and one and two Trombe walls in the façade. The results show an important reduction in the energy consumption with the use of Trombe walls and double self-cleaning glazing in the façade, which also presented better daylighting performance.
\end{abstract}

Keyword: Façade; Energy Efficiency; Trombe wall; Glazing; Daylighting. 


\section{INTRODUCTION}

Over the last decades, façade technologies have undergone substantial innovations in both quality of materials/components and overall design concept of the façade system by integrating specific elements to adapt the mediation of the outside conditions to the user's requirements. These improvements include passive technologies, such as multi-layered glazing, sun protections, ventilation [1] and Trombe walls.

Edward Morse was the first to describe the Trombe wall concept in a patent [2]. However, the idea was re-patented and popularized by French engineer Felix Trombe and architect Jacques Michel [3]. Since ancient times, people have used thick walls of either adobe or stone to store the solar energy captured during the day and release it slowly and evenly at night to heat buildings. Presently, lowenergy buildings can use this ancient technique by integrating a thermal storage and delivery system called "Trombe wall" [4].

A typical Trombe wall (TW) consists of a 10 to $40 \mathrm{~cm}$ thick south-oriented wall (northern hemisphere) faced with a single or double layer of glass, which is placed 2 to $5 \mathrm{~cm}$ from the massive wall to create a small airspace. To increase the absorptivity of the solar radiation, the surface of the massive wall is usually painted black [5]. The heat from the sunlight passing through the glass is absorbed by the dark surface, stored in the wall, and slowly conducted inwards through the wall. High-transmission glass maximizes solar gains to the wall. As an architectural detail, patterned glass can limit the exterior visibility of the dark concrete wall without sacrificing transmissivity. For a $20 \mathrm{~cm}$-thick Trombe wall, it will take the heat approximately 8 to 10 hours to reach the interior of the building, slowly warming it and reducing the need for conventional heating [4].

According to researches, Trombe walls are an effective technology that reduces up to $47 \%$ of the heating energy in residential cases [6] and, therefore, can be used as an efficient and durable solar heating method.

Several studies on Trombe walls have been carried out recently. Sadineni et.al [7] presented a building envelope components and passive solutions review. A comparative study using numerical simulations was conducted for four different types of solar wall configurations: unventilated solar wall, Trombe wall, insulated Trombe wall and composite solar wall. All of these walls, except the unventilated solar wall, transfer heat to the indoor environment by both conduction through wall and convection through circulating air. The unventilated solar wall transfers heat exclusively through 
conduction [8]. Jie et al. [9] proposed an innovative design of PV integrated Trombe walls. In this design, PV cells are affixed on the back of the transparent glass cover of a normal Trombe wall. Both the heat rejected by the PV cells and the heat absorbed by the thermal mass of the Trombe wall are used for space heating. In another study, Trombe walls that use a phase change material (PCM) were reviewed [10] and the experimental results showed that PCM Trombe walls were thinner and also performed better than concrete walls.

The apparent amenity of the climate in Portugal has led to the non-existence of central heating or cooling systems in most parts of the buildings, except service buildings. Gonçalves et al. (1997) [11] conducted a study entitled "Passive Solar Buildings in Portugal: Experiences in the Last 20 years", in which they described some uses of Trombe walls. A residential building called Vale Rosal (Figure 1), located in Charneca da Caparica, Lisbon, has a 3,5 $\mathrm{m}^{2}$ Trombe wall. The Schäfer Residence (Figure 2) located in Porto Santo, Madeira, has a Trombe wall whose area is $12 \mathrm{~m}^{2}$.

Figure 1. ". Vale Rosal Building (Charneca da Caparica-Lisbon).

Reference: Gonçalves et al., 1997 [11].
Figure 2. Schäfer Residence (Porto SantoMadeira).

Reference: Gonçalves et al., 1997 [11].

According to Gonçalves et al. (1997) [11], the Trombe walls in Portugal cover 2 to $6 \%$ of the floor area $\left(3.5 \mathrm{~m}^{2}\right.$ up to $\left.33 \mathrm{~m}^{2}\right)$. Wall thicknesses of 15 to $40 \mathrm{~cm}$ were found in their research. Most walls do not have any vents and the glazing used is single. In terms of summer protection, some use movable or fixed shading devices and others do not have any solar protection at all. Figure 3 shows an example of a Trombe wall in Portugal with the largest area $\left(33 \mathrm{~m}^{2}\right)$. It is a nursery located in Mertola.

Figure 3. Nursery (Mertola)

Reference: Gonçalves et al., 1997 [11].

Computer simulations offer a variety of tools that can be used to test passive solutions and foresee their performance in a more economical and less time-consuming way. Ellis (2003) [12] validated the use of EnergyPlus for an unvented Trombe wall model and the results were compared to experimental data. According to the author, users should not hesitate to use the model for the simulation of passive solar buildings. 
In our research, the software program used for the analyses of the thermal performance was DesignBuilder v. 1.8, a graphic interface for EnergyPlus, which enabled to obtain heating energy needs for the use of passive solutions. The results of "Standard Method of Test for the evaluation of Building Energy Analysis Computer Programs" for DesignBuilder agreed with the equivalent results for the EnergyPlus simulation engine. For the analyses of the daylighting performance, Ecotect and Desktop Radiance programs were used to obtain illuminance levels and daylight factor (DF) for glazings. These types of computer programs can also be used for the development of new façade systems.

\subsection{Modular Façade System}

Various façade system producers and architects have recently developed service-integrated façades. These are composed of parts with fixed glazing, operable windows and decentralized HVAC service installations. Facility managers, climate designers and manufacturers of HVAC components are involved in the development of integrated processes. As every façade element is equipped with HVAC installations, it is easy to provide individual comfort control for every office space, for example. Disadvantages of such systems involve the lack of compatibility with operable windows [13]. I modul (Figure 4), Temotion (Figure 5), and Capricorn (Figure 6) are examples of modern façade systems.

Figure 4. I modul- Figure 5. Temotion Façade. Façade Panels inside. Reference: Wicona Productos y Reference: Treberspurg; Referencias. Temotion, 2009 Djalili (2010) [14].
[15].
Figure 6. Capricorn Façade.

Reference: Treberspurg; Djalili (2010) [14].

Façade I-modul is a cladding system with integrated building services for heating, cooling, ventilation, heat recovery, lighting and sound insulation. Unitized cladding panels are merely $20 \mathrm{~cm}$ deep [14]. Wicona-Hydro Company, Fachhochschule Biberach, and the Universität Dortmund have developed a façade that includes a number of functions, like optimized energy management, automatic adjustment of heating and cooling needs and natural and mechanical ventilation. Sun and glare shields are also integrated in the façade, therefore it is possible to regulate the daylight admission and lighting, as well as the color of the light [15]. 
In the Capricorn system, optimized building equipment (heating, cooling and ventilation) and renewable energy are integrated in the façade panels, which are used mainly for office buildings. The Capricorn Haus Düsseldorf was developed by Trox and Schueco Company. The design of the façade includes transparent and opaque components, combined visibility, natural light and reduction in solar gains, in comparison to conventional curtain walls.

The ideal goal would be dynamic and flexible improvements to adapt the façade to the climatic changes, the occupant's requirements and the building. An improvement would be the development of a suitable system to facilitate the assembly of the façade. Other elements, as passive solutions, glazing and reception of solar energy are also important. In agreement with the climatic needs and to improve comfort conditions, different solutions can be proposed according to the solar orientation and desired functions in the façade system.

In the "Façade Modules for Eco-efficient Refurbishment of Buildings" system [16] [17] [18], the differentials are the versatility and flexibility of the modules $(60 \times 60 \mathrm{~cm}$ single modules). These modules allow a different architectural approach for each application. Versatility and flexibility features are not usually found in façade systems, which generally comprise all functions in a single module. These small modules can be installed in the façade and combined in different ways according to the needs, climate and available solar radiation. Figure 7 shows the main idea of the system; however the description of the modules is not the main objective of this paper.
A. Standard fixed
B. Standard awning
C. Sunshade module.
D. Ventilation module.
E. Sunspace module F. PV module.
F. PV module.
G. Trombe wall module.
H. Trombe wall support to massive wall.

Figure 7. Main idea of the modular façade system.

The modules discussed in this paper are the standard fixed (Figure 7A) and awning glazed (Figure $7 \mathrm{~B}$ ) modules and Trombe wall module (Figures $7 \mathrm{G}$ and $7 \mathrm{H}$ ). To build the massive wall of a Trombe wall, the concrete is cast inside a support (Figure 7) and the Trombe wall module is assembled in front of this support (Figure 7G). The paper shows partial results of an ongoing investigation into glazing modules of this modular system, focusing on the thermal performance of Trombe walls and glazing modules and daylighting performance of glazing modules. 


\section{MATERIALS AND METHODS}

\subsection{Computational Simulations of Thermal Performance}

Computational simulations were carried out applying DesignBuilder 1.8 software to analyze a case study, which consists of a room $\left(25 \mathrm{~m}^{2}\right)$ with different arrangements of façade modules. The following parameters were considered for the simulations:

(i) Two different double glazing types (composed of green solar control glass and low-e glass, self-cleaning glass and float clear glass);

(ii) One or two Trombe walls;

(iii) Four solar orientations (northern, southern, eastern and western);

(iv) Two envelopes: a conventional Portuguese system (double masonry) and a light gauge steel framing system (LGSF);

(v) Four different Portuguese climates.

For validation purposes, the values of the heating energy needs obtained in the thermal simulations were compared with the ones calculated in accordance with the Portuguese thermal regulation for residential buildings - "Regulamento das Características do Comportamento Térmico dos Edifícios RCCTE” [19].

For the thermal performance simulations the climate of four Portuguese cities (Lisbon, Oporto, Lajes and Funchal) (Table 1) was analyzed. The simulations were carried out for four solar orientations (northern, southern, eastern and western) considering the annual period, and a façade with one or two set modules of Trombe walls was used in the simulations.

Table 1. Climates for Computational Simulations

\subsubsection{DesignBuilder}

DesignBuilder software is a friendly graphic interface for the EnergyPlus simulation engine program (Figure 8). Developed for use at all stages of a building design, DesignBuilder combines the state-ofthe-art thermal simulation software with an easy-to-use interface. It allows the calculation of the building energy use, evaluation of façade options for overheating and visual appearance, visualization of site layouts and solar shading, thermal simulation of naturally ventilated buildings, analyses of lighting control systems, calculation of heating and cooling equipment sizes, etc. 
Figure 8. Main screen of DesignBuilder software.

In DesignBuilder, there is no Trombe wall object per se; rather, it is composed of other standard building components. This approach provides flexibility to incorporate Trombe walls and specifies the various wall parameters and freedom to explore unusual configurations. To simulate a Trombe wall, a very narrow zone is coupled to the desired surface via an interzone partition. Optimally, the window covers nearly all the wall area and has very high transmissivity to allow a maximum amount of solar flux into the Trombe zone.

Before initiating the simulations it is important to make sure the solar distribution has been set to "Full Interior and Exterior", so that most solar flux is directed to the absorber surface and not only to the small area of the Trombe zone floor.

The zone type on the Activity tab should be set to "Cavity", causing the following changes to the model:

- The zone is set as unoccupied by loading <None > Activity, HVAC and Lighting template data.

- Suspended floors and ceilings are switched off when separate constructions are used.

- The "cavity" Internal convection algorithm is set for cooling design, heating design and simulation calculations to correctly model the air space. This algorithm correctly calculates the convection coefficients for a narrow sealed vertical cavity based on the ISO 15099 standard.

- The "Full interior and exterior" solar distribution algorithm is set for cooling design and simulation calculations because it allows the solar radiation to be accurately distributed onto internal surfaces of the zone.

The algorithm cavity correctly calculates the convection coefficients for a narrow sealed vertical cavity based on the ISO 15099 standard and analyzes the Trombe wall zone to find the two major surfaces, setting the coefficients for those surfaces. The other minor surfaces receive negligible convection [20]. For a naturally ventilated Trombe wall, there exists no built-in algorithm to calculate the correct convection coefficients inside the cavity walls. An option is to use the "Detailed" algorithm of inside convection. It takes into account some natural convection effects, but it is intended for a normally sized room. It is possible to define holes and vents through the Trombe wall by drawing them on a surface level. Vent openings can be scheduled and controlled by the internal temperature [20]. 
In this research "cavity" and "detailed" inside convection algorithms were tested in DesignBuilder, but as the values of the heating needs were similar, considering a small ventilation area $\left(0.10 \times 0.20 \mathrm{~m}^{2}\right)$, the cavity inside convection algorithm was used.

The results of "Standard Method of Test for the evaluation of Building Energy Analysis Computer Programs" for DesignBuilder agreed with the equivalent results for the EnergyPlus simulation engine. They showed that DesignBuilder generated correct input data for EnergyPlus, adding confidence to the results generated by DesignBuilder/ EnergyPlus [21]. Most results for DesignBuilder were identical to those extracted from the Gard Analytics report for EnergyPlus run in standalone mode [22].

\subsubsection{Definition of Standard Model for Thermal Performance}

The "standard model" was defined considering a one-storey isolated room, of regular 5,0 x 5,0 $\left(25 \mathrm{~m}^{2}\right)$ geometry and ceiling height of $2,80 \mathrm{~m}$. These dimensions followed the recommendations of the Portuguese Urban Building Regulation "Regulamento Geral das Edificações Urbanas" [23]. The total dimension of the façade modules was $2,5 \times 2,5\left(6,25 \mathrm{~m}^{2}\right)$. The standard model was simulated considering the implementation of one and two Trombe walls. A set of five Trombe modules makes a complete "Trombe wall" (Figures 9 and 10).

Figure 9. Model: One Trombe wall.

Figure 10. Model: Two Trombe walls.

For the Trombe wall module, the use of a double glazing with high shading coefficient was considered. The double glazing had two panes made of $4 \mathrm{~mm}$ Diamant glass (Saint-Gobain Glass) and 12mm air space, allowing maximum solar radiation penetration. The area of a complete Trombe wall composed of five modules is $0.50 \times 2.50 \mathrm{~m}\left(1.25 \mathrm{~m}^{2}\right)$. Higher and lower modules had ventilation openings on the massive wall, whose area was $0.02 \mathrm{~m}^{2}\left(0.10 \times 0.20 \mathrm{~m}^{2}\right)$, as previously mentioned. The operating time considered for such openings was 9:00 to 18:00 in the winter; in the summer the openings remained closed during the day and opened at night.

Based on the RCCTE (Portuguese Code), the conventional season of heating (winter) starts in the first ten-day period subsequent to October 1 , wherein for each location the average daily temperature is below $15^{\circ} \mathrm{C}$, and ends in the last ten-day period prior to May 31 , whose temperature is still below $15 \stackrel{\circ}{\circ}$. The conventional season of cooling (summer) comprehends four summer months (June, July, 
August and September). In these months there is greater likelihood of high outside temperatures, which may require the cooling of the environment in buildings with small internal loads.

In the simulations, the Trombe walls were active during the winter period (scheduled for hours and months of winter). The period of the conventional season of heating was used for the operation of Trombe walls, permitting the entry of solar radiation between 9:00 am and 18:00.

A Portuguese conventional construction system (double-wall masonry) and a light gauge steel framing system (LGSF) were considered in the model for the opaque envelope. The conventional system is composed of lightweight concrete slabs and insulation (Extruded Expanded polystyrene - EPS), plaster and a waterproofing coating layer. The external walls of the model are made of double masonry with interior insulation, air space and cement mortar plaster (Figures 11 and 12).

Figure 11. Portuguese Conventional System: Roof Slab.

Figure 12. Portuguese Conventional System: Wall.

The LGSF envelope composition was based on the work of Santos et al. (2011) [24]. Lightweight concrete, rock wool, gipson board, OSB, ceramic and air space compose the light gauge steel framing system slab. EIFS (External Insulation and Finish System), OSB boards, rock wool and gypsum plasterboard were used in the walls (Figures 13 and 14).

Figure 13. Light Gauge Steel Framing System: Roof Slab.

Figure 14. Light Gauge Steel Framing System: Wall.

In this case, instead of a real roof, only an insulated slab was considered to highlight the thermal performance of the façade solutions and focus on the thermal performance of those modules. Table 2 shows the overall heat transfer coefficient values - U-factor $\left(\mathrm{W} / \mathrm{m}^{2} \stackrel{\circ}{ }{ }^{\circ}\right)$ for a Portuguese conventional construction system and light gauge steel framing system.

Table 2. Overall Heat Transfer Coefficient $\left(\mathrm{W} / \mathrm{m}^{2} \stackrel{\circ}{ } \mathrm{C}\right)$ 


\subsubsection{Types of Glazing}

Important factors, such as solar factor (or g-value), solar heat gain coefficient, shading coefficient, transmittance, and U-factor resulting from the glazing composition must be observed in the selection of the glazing. The glasses selected for the standard façade module simulations were supplied by Saint-Gobain Glass. Table 3 shows the main properties of the simple glasses.

Table 3. Types of glass for the standard module.

The glasses were used in the computational simulations with DesignBuilder software to obtain heating energy needs for all climates. Furthermore, a $12 \mathrm{~mm}$ air layer between the outermost and inner panes was considered. The values were obtained by Window 6.2.33.0 software [25]. Table 4 shows the glazing compositions based on the types of glasses in Table 3. According to the manufacturer, cool Lite KNT 155 green is a temperable solar control glass, planitherm futur ultra $\mathrm{N}$ is a glass of extremely low emissivity, bioclean is a self-cleaning glass, planilux is a multi-purpose clear float glass, and diamant is a clear float glass.

Table 4. Glazing Properties.

\subsubsection{Internal Gains and Reference Temperatures}

The Portuguese Thermal code (RCCTE) [19] describes $4 \mathrm{~W} / \mathrm{m}^{2}$ as an average value for the total internal gains (occupation, lighting and equipment). However, due to possibilities and simulation options offered by the DesignBuilder software, the internal gains were separated for the occupation, lighting and equipment (Table 5).

Table 5. Internal Gains $\left(\mathrm{W} / \mathrm{m}^{2}\right)$

As RCCTE standard does not establish schedules (days of the week, hours and time) of occupation, lighting and equipment use for residential buildings, the values were obtained from Sousa (2008) [26] (Figures 15 to 18 ). Values of $20^{\circ} \mathrm{C}, 25^{\circ} \mathrm{C}$ and 0.6 air changes per hour were considered the references for heating indoor temperature (winter), cooling indoor temperature (summer) and natural ventilation rate, respectively, in agreement with RCCTE [19].

Figure 15. Occupation Schedule.

Figure 16. Lighting Schedule.

Figure 17. Equipment Schedule. 
Figure 18. Ventilation Schedule.

The DesignBuilder software offers some options to indicate the data of simulations on the screen and information about internal gains. Furthermore the graphic of results shows the contribution of each element (General Lighting, Equipment, Occupancy, Solar Gains Exterior Windows).

The options to visualize the data of simulations are "all", "Site data", "Comfort", "Internal gains" and "Fabric and ventilation." The "Internal gains" data option provides information about general lighting, computer and equipment, occupancy, solar gains exterior windows and zone sensible heating and cooling.

Description of each item:

- General Lighting - heat gain due to general lighting.

- Computer and Equipment - heat gain due to computer and other IT-related equipment.

- Occupancy - sensible gain due to occupants. It can vary depending on the internal conditions.

- Solar Gains Exterior Windows - (used to be called 'Transmitted solar gains'). Short-wave solar radiation transmission through external windows. For a bare window, this transmitted radiation consists in the solar radiation passing through the glass and diffuse radiation from solar radiation reflected from the outside window.

- Zone/Sys Sensible Heating - heat delivered to maintain the internal heating design temperature. It is the sensible heating effect of any air introduced into the zone through the HVAC system including any 'free heating' due to the introduction of relatively warm outside air and the heating effects of fans.

- Zone/Sys Sensible Cooling - sensible cooling effect on the zone of any air introduced through the HVAC system. It includes any 'free cooling' due to the introduction of relatively cool outside air. Cooling always shows a negative heat gain in the results.

However, the value analyzed in the results is the zone/sys sensible heating, which indicates the heat delivered to maintain the internal heating design temperature. In the simulations the main contribution to the heating of the environment was the exterior windows, in this case from glazing systems (Trombe wall and glazing). 


\subsubsection{Heating Energy Needs}

The values of heating energy needs are provided for four solar orientations (northern, southern, eastern and western), considering the annual period. The analysis of the results was based on the estimate of the values of heating energy needs, obtained according to the RCCTE energy calculation method for Lisbon, Oporto, Lajes-Azores and Funchal-Madeira.

The results of the computer simulations for each façade configuration were compared considering the delivered or maximum nominal energy for heating $(\mathrm{N} I)$. According to Article 15 of the Portuguese Thermal code, the limits of $\mathrm{Ni}$ of a building unit $\left(\mathrm{kWh} / \mathrm{m}^{2}\right.$.years) depend on the values of the form factor $(F F)$ and degree-days $(D D)$ of the local climate. In the "standard model" $\left(5 \times 5 \mathrm{~m}^{2}\right.$ area, $2.80 \mathrm{~m}$ ceiling height), the form factor (FF) was:

$$
\begin{gathered}
\qquad F F=\left[A_{\text {out }}+\Sigma\left(\tau A_{\text {ins }}\right)_{i}\right] / V \\
A_{\text {out }}=81 \mathrm{~m}^{2} \text { (Summation of outside envelope areas) } \\
A_{\text {ins }}=0 \text { (Summation of inside envelope areas) (There are no inside walls) } \\
V=5 \times 5 \times 2,8=70 \mathrm{~m}^{3} \text { (Inside Volume) } \\
\text { Then } F F=1,16
\end{gathered}
$$

For a form factor between $1<F F \leq 1,5$

$$
N i=[4,5+(0,021+0,037 F F) D D](1,2-0,2 F F)
$$

The results were analyzed based on the maximum nominal energy for the heating $(N i)$ value calculated according to RCCTE.

\subsection{Computer Simulations of Daylighting Performance}

The daylighting was evaluated for the same model studied in terms of thermal performance. Interior illuminance levels were determined based on a square mesh of points spaced approximately $0.125 \mathrm{~m}$, on a horizontal plan $0,8 \mathrm{~m}$ above the floor to study the daylight incidence on the working surface. The mesh distance from the interior walls was approximately $0.1 \mathrm{~m}$. The daylight factor (DF) obtained was calculated by Ecotect 5.6 from the arithmetic mean points defined by the mesh. Based on the results, the acceptable conditions of illuminance level and daylight factor (DF) were verified.

No operation schedule was used for artificial light in the daylighting simulations, because only the daylight factor and illuminance levels were evaluated for the summer (June 21) and winter (December 
21) solstices at 12:00 P.M. without artificial light source. The occupation of the model consisted of two people exactly as in DesignBuilder software, and the occupation schedule was the same. No value of setting indoor temperature was used in Ecotect.

The net glazing area (window area minus mullions and framing, or $\sim 80 \%$ rough opening) divided by the gross exterior wall area (e.g., multiply width of the bay by floor-to-floor height) equals the windowto-wall ratio [27]. Considering the total dimension of the façade $\left(6,25 \mathrm{~m}^{2}\right)$, the use of two passive Trombe walls implied a minimum glazing area with a window-to-wall ratio (WWR) of 19\%, as shown in Table 6.

Table 6. Façade Settings for Daylighting Performance Simulations.

Table 7 shows the values of the surfaces reflectance that characterize the room under study. These values are recommended to the interior surfaces of a room [28].

Table 7. Reflectance of Materials

\subsubsection{Ecotect 5.6}

Ecotect 5.6 tool offers a range of lighting analysis options. The main focus is on daylighting analysis. It implements the Building Research Establishments (BRE) split flux method to determine the levels of natural light at points within a model. The Building Research Establishments (BRE) is based on the Daylight Factor concept, which is the ratio of the illuminance at a particular point within an enclosure to the simultaneous unobstructed outdoor illuminance.

The BRE method of daylight factor (FLD) excludes indirect gain solutions resulting from the reflection of light on multiple surfaces to illuminate a space, considering only the direct gain. The software can analyze these natural lighting conditions using two types of sky, i.e. overcast and uniform, which correspond to standard models of the "Commission International of L'eclairage" (CIE). Figure 19 shows the main screen of Ecotect for the daylighting calculation.

Figure 19. Ecotect Main Screen.

Presently, the new version of Ecotect software is "Autodesk Ecotect Analysis". It is now sustainable design analysis software with a comprehensive concept-to-detail sustainable building design tool. 
It is an environmental assessment tool that allows simulating a model in terms of thermal, acoustic and lighting performance, with several detailed analysis functions and a visual and interactive display that shows test results directly within the model of the building. A study on the development of "Ecoefficient Window" [29] results shows that the average values for the illuminance levels and daylight factor (DF) obtained by Ecotect software are similar to those measured in experiments, ranging, in this case, from $4 \%$ to $7 \%$.

Ecotect Analysis offers a wide range of simulations and building energy analysis functionalities, which can improve the performance of the existing buildings and new building designs. This new version also allows simulation types shown in older versions (thermal performance, solar radiation and daylighting) and whole-building energy analysis, water usage and cost evaluation, shadows and reflections [30].

For a correct assessment of the values in the daylighting simulations it was necessary to generate climate files from "epw" file (EnergyPlus) to ".wea" file in Ecotect 5.6. According to the latitude of the location, the outside illuminance is calculated. Although the exterior illuminance obtained by Ecotect software shows some differences in relation to the real situation, it is known that such values depend on the latitude of the city and do not affect the daylight factor obtained by the computational simulations.

According to Autodesk [31], Ecotect Analysis follows various international standards for the different analyses it conducts. To be compliant with building regulations, Ecotect Analysis implements the BRE Split Flux Method for daylighting calculations, conforming to "BS 8206-2-1992 Lighting for buildings, Code of practice for daylighting" and relevant elements within "BS 8206-1-1985 Lighting for buildings, Code of practice for artificial lighting". It also uses "BS ISO 15469-1997 Spatial distribution of daylight - CIE" standard overcast sky and clear sky for its illuminant distribution model. Ecotect Analysis uses Radiance as the design model becomes more refined and therefore suitable for a detailed radiantexchange analysis. All the solar positions, solar radiation and thermal load calculations have been validated against "CIBSE TM33 (2006) Tests for Software Verification and Accreditation". Solar access and rights-to-light calculations conform to the "BRE Site Planning Handbook". Ecotect Analysis specific use of the admittance method is based on "ISO 13791:2004 Thermal performance of buildings" and "ISO 13792:2005 Thermal performance of buildings", as well as parts of "ISO 13789:1999 Transmission heat loss coefficient - Calculation method". Ecotect Analysis calculates only 
demand loads, therefore many of the energy use validation tests, such as BESTEST and ASHRAE are not directly applicable.

As Ecotect software has been used to obtain illuminance level and daylight factor on a working plane $85 \mathrm{~cm}$ above the floor level, simulated for summer overcast and sunny sky conditions [29] [32] [33] [34], it can be considered accurate.

Ibarra \& Reinhart [33] performed study on daylighting comparing Ecotect, Daysim and Radiance programs and concluded that the results of the latter are more reliable than the results of the others. A "best practice" model was created by the authors using Ecotect. Krüger et al [34] developed an analysis based on computer simulations. At a first stage, the impact of different siting possibilities was tested. Simulations were carried out with Ecotect and Radiance. Ecotect was used to input the 3D geometry of a school building and its orientation, define view cameras in the classrooms and perform simulations with overcast sky. Moreover, geometry definitions, orientations and view cameras were exported to the Radiance Synthetic Imaging System, which allowed the rendering of indoor lighting levels under overcast sky and clear sky conditions.

\subsubsection{Desktop Radiance 1.02}

For a more detailed and accurate analysis of the daylight factor and illuminance level, the Ecotect model should be exported directly to tools, like Desktop Radiance and Daysim. The development of the Desktop Radiance started in 1984 at the Lawrence Berkeley Laboratory (Berkeley, USA). At the same time, the "radiosity" method was first applied to the computer graphics domain. The "ray tracing" method used since the 1970s was considered incapable of computing interreflections in a reasonable amount of time. The most original part of Radiance lies within its interreflection calculation algorithm, which uses a backward ray tracing method. The Desktop Radiance version is a more user-friendly derivative of this software and runs under the Windows operating system. This user-friendly interface makes most of the complex Radiance commands transparent to the user [35].

Desktop Radiance is a design tool that facilitates the design and analysis of buildings to optimize the efficiency of daylighting systems and lighting technologies. It allows computing horizontal illuminance across an arbitrarily oriented grid of points or generating an image of a space that can be queried for the illuminance or luminance of any surface in a rendered figure of a room. 
For the illuminance analyses, the model is saved as ".rad", which is the Radiance file. Units of lux and surface and/or point analysis have to be chosen to calculate illuminances, i.e. numerical illuminances as well as pictures rendered will be calculated. The illuminance is calculated at points on the analysis grid. Sky conditions, date and time have to be chosen. Interior views of the model can be seen if appropriate cameras are set. Ecotect must recognize the path of Radiance on the computer. When the Radiance simulation is finished, the rendering pops up first inside a viewer. By running the mouse over the pictures that appear, it is possible to see the illuminance at each pixel and also record the illuminance on the picture by clicking on different pixels. Different overlays, such as "falsecolor" and "human sensitivity" are available for the exhibition of results.

The other output of Radiance software is the illuminance data on the work-plane, calculated for this study. When the Radiance viewer is closed or minimized, a small window pops up. The Ecotect screen will show the data in detail. When the result is imported to Ecotect, the illuminance levels calculated appear on the screen, according to the Radiance method results.

\subsubsection{Daylight Factor (DF)}

The daylight Factor (DF) is the most widespread parameter for the characterization and quantification of daylighting conditions in buildings. It is defined as the quotient (expressed as a percentage) between illuminance (at a given point on a plan inside a room, due to a distribution of sky illuminance measurements known) and the outside luminance on a horizontal plane.

It is a significant parameter to quantify the daylighting under overcast sky conditions. However, under certain conditions it has limitations. For example, under partly cloudy sky conditions, it may be 0.2 to 5 times above the total amount for overcast skies [36]. Therefore, an overcast standard CIE is considered in the computer simulations of luminous performance.

If on overcast sky daylighting is satisfactory, on sunny days it will probably be adequate to overcast standard CIE sky. The daylight factor of an optimized construction in terms of daylighting allows a maximum solar radiation entrance, which may be harmful to the conditions of comfort. However, the DF does not allow verifying the illuminance levels recommended to achieve a particular visual task. Table 8 shows the indicated daylight factor.

Table 8. Daylight Factor for Residential Buildings. 


\subsubsection{Illuminance Levels}

For an overcast sky, regardless of the solar orientation, as the level of radiation is the same, the effect of the orientation factor does not appear in the daylight factor calculation. However, the simplification of the use of DF does not consider the location and building orientation, season, time of day, radiation direct effect and variation of conditions and sky. It is necessary to observe the illuminance levels on specific days as in the summer and winter solstices, for example.

For the evaluation of illuminance levels within the space, the summer (June 21) and winter (December 21) solstices (Figure 20), at 12:00 P.M., overcast sky standard CIE and southern solar orientation were considered. The southern solar orientation was chosen because it provided the best results in previous studies on thermal performance.

Figure 20. Conditions of Daylighting Simulation: 3D Illustrative diagrams (a) (b).

To determine the illuminance levels and the DF, a distribution of CIE Standard Overcast Sky luminance was considered. The llumination level was calculated according to the latitude of the city, with different values for each city analyzed by Ecotect 5.6. The results were compared with recommended values (Table 10).

Table 9. Illuminance by City.

Table 10. Illuminance Level: Residential buildings

\subsubsection{Transmittance Curve and Daylighting Performance}

The spectral transmittance depends on the chemical composition of the material, color, optical absorption within the material and glass surface characteristics. A reduction in the radiation transmission almost always means that this radiation has been absorbed by the glass, resulting in an increase in the temperature of the material [40].

Spectrophotometric behavior is an important factor for the specification of transparent materials. Transmittance is the ratio of the total radiant or luminous flux transmitted by a transparent object to the incident flux, usually given by the normal incidence of the solar radiation. The visible light region is a part of the spectrum that our eyes can detect. It ranges in wavelengths from approximately 380 to $780 \mathrm{~nm}$. In fact it depends on the sensitivity of each person's eyes. A higher value of visible transmittance leads to a better performance of a glass in terms of daylighting [41]. 
A transmittance curve for the simulated glazings is shown to confirm the results. The sample space available in the spectrophotometer did not allow the air layer between the glass panes to be $12 \mathrm{~mm}$, as in the thermal simulations previously accomplished. However, spectrophotometric tests were conducted considering a $6 \mathrm{~mm}$-thick air layer. Despite this difference, the results were significant in the analysis. These tests allowed checking the influence of the glasses and air layer on the double glazing transmittance [40] [41].

\section{RESULTS}

\subsection{Thermal Performance}

This section shows the results of heating energy needs, considering the annual period for four solar orientations (northern, southern, eastern and western). An analysis based on the estimate of the heating energy needs for Lisbon, Oporto, Lajes (Azores) and Funchal (Madeira) was conducted using the RCCTE energy calculation method.

In order to better understand the results, it must be noted that:

(i) $1 \mathrm{TW}=$ Five Trombe wall modules make one total Trombe wall;

(ii) $2 \mathrm{TW}=$ Two sets of five Trombe wall modules make two Trombe walls.

The validity of the results provided by Design Builder software was proven by comparing the values for the heating energy needs in the simulations and the values calculated according to the Portuguese code RCCTE for each climate. The proximity of these values shows the consistency of the results. If the results of the simulations had showed major differences regarding the values calculated based on the Portuguese code, they would not have been close to reality.

The analyses of results also show a comparison in percentage between the energy consumption for the heating of the glazing façades (glazings 04 and 07) and the energy consumption for heating using passive solutions (Trombe walls). This percentage was calculated based on the average of energy savings and considering the four solar orientations and the building envelopes analyzed. The values indicate the percentage of energy saved using passive solutions. 


\subsubsection{Lisbon}

The heating energy needs resulting mainly from façades with passive solutions analyzed for the climate in Lisbon were lower than the maximum value allowed by the Building Thermal code RCCTE $\left(56.36 \mathrm{kWh} / \mathrm{m}^{2}\right.$.year) for that climate (Figure 21). The values yielded by the use of glazing solutions only as a reference (Glazing 04 and 07 ) were an exception because they indicated higher heating energy needs for the northern solar orientation, mainly for the conventional envelope. This solar orientation receives less radiation during the year (northern hemisphere), therefore it requires more heating energy.

The solution for the façade with Glazing 07 and one or two Trombe walls showed better results in comparison with the other types of façades. The heating energy needs were similar for both envelopes analyzed. The results for one or two Trombe walls with the characteristics listed above were practically identical (Figure 21).

Figure 21. Lisbon: Heating Energy Needs. Conventional System (a) and LGSF System (b).

For the LGSF system envelope and comparing the results of energy heating needs for Lisbon, average decreases of $15 \%$ and $23 \%$ were observed with the use of glazing 04 and one Trombe wall and glazing 04 and two Trombe walls, respectively. Average decreases of $7 \%$ and $9 \%$ in the energy heating needs were achieved with the use of glazing 07 and one Trombe wall and glazing 07 and two Trombe walls, respectively. For the conventional system envelope and comparing the results of energy heating needs for Lisbon average decreases of $12 \%$ and $17 \%$ were achieved with the use of glazing 04 and one Trombe wall and glazing 04 and two Trombe walls, respectively. Average decreases of $13 \%$ and $10 \%$ were observed with the use of glazing 07 and one Trombe walls and glazing 07 and two Trombe walls, respectively.

\subsubsection{Oporto}

Taking into account the results shown in Figure 22, for the climate in Oporto, the heating energy needs resulting from mainly the façade analyzed were lower than the maximum value allowed by RCCTE (74.66 $\mathrm{kWh} / \mathrm{m}^{2}$.year) for that climate. The values yielded by the use of glazing solutions only as a reference (Glazing 04 and 07) were an exception because they indicated higher heating energy needs for the northern solar orientation, mainly for the conventional envelope. This solar orientation 
receives less radiation during the year (northern hemisphere), requiring more heating energy, indicating that the use of a Trombe wall along with the glazing causes a decrease in the heating energy.

Glazing 07 and one or two Trombe walls showed better results in comparison with the other façades. For the southern solar orientation, an important energy saving with the passive solutions integration was observed. The heating energy needs showed similar values for both envelopes.

Figure 22. Oporto: Heating Energy Needs. Conventional System (a) and LGSF System (b).

For the LGSF system envelope and comparing the results of energy heating needs for Oporto, average decreases of $17 \%$ and $23 \%$ were achieved with the use of glazing 04 and one Trombe wall and glazing 04 and two Trombe walls, respectively. Average decreases of $7 \%$ and $9 \%$ were observed in the energy heating needs with the use of glazing 07 and one Trombe wall and glazing 07 and two Trombe walls, respectively.

For the conventional system envelope and comparing the results of energy heating needs for Oporto, average decreases of $12 \%$ and $16 \%$ were achieved with the use of glazing 04 and one Trombe wall and glazing 04 and two Trombe walls, respectively. Average decreases of $9 \%$ and $8 \%$ were observed in the energy heating needs with the use of glazing 07 and one Trombe wall and glazing 07 and two Trombe walls, respectively.

The use of two Trombe walls for the LGSF envelope showed small differences of $2 \%$ and $1 \%$, increasing the heating energy needs in relation to the use of one Trombe wall. Such a difference was not expected, because two Trombe walls should decrease the heating energy needs, as in the results showed for the other climates. This error probably occurred due to problems in the engine of the simulation programs. Moreover, the proposed Trombe walls do not have a large area in comparison with the total area of the façade, floor area and the environment volume. In our research [42], nine climates of Portugal were analyzed, but this error occurred only for the climate of Oporto. Even by repeating the procedure and revising the parameters the error persisted.

\subsubsection{Lajes - Azores}


For the climate in Lajes (Azores), the heating energy needs resulting from the use of all façades analyzed were lower than the maximum value allowed by RCCTE $\left(36.42 \mathrm{kWh} / \mathrm{m}^{2}\right.$.year) for that climate (Figure 23). Glazing 07 used in the façade with one or two Trombe walls again showed better results in comparison with the other types of façades. The values of the heating energy were lower for the light gauge steel framing envelope. In general, the results were identical when one or two Trombe walls and glazing 07 were used.

Figure 23. Lajes-Azores: Heating Energy Needs. Conventional System (a) and LGSF System (b).

For the LGSF system envelope and comparing the results of energy heating needs for Lajes, average decreases of $30 \%$ and $38 \%$ were observed with the use of glazing 04 and one Trombe wall and glazing 04 and two Trombe walls, respectively. Average decreases of $8 \%$ and $12 \%$ were achieved in the energy heating needs with the use of glazing 07 and one Trombe wall and glazing 07 and two Trombe walls, respectively. For the conventional system envelope and comparing the results of energy heating needs for Lajes, average decreases of $14 \%$ and $22 \%$ were observed with the use of glazing 04 and one Trombe wall and glazing 04 and two Trombe walls, respectively. Average decreases of $8 \%$ and $9 \%$ in the energy heating needs were observed with the use of glazing 07 and one Trombe wall and glazing 07 and two Trombe walls, respectively.

\subsubsection{Funchal-Madeira}

For all types of façade analyzed for the climate in Funchal (Madeira), the heating energy needs were lower than the maximum value allowed by RCCTE $\left(46.42 \mathrm{kWh} / \mathrm{m}^{2}\right.$.year) for that climate in the model analyzed (Figure 24). The façade solution with glazing 07 and one or two Trombe walls showed better results. For the northern orientation, the variation in the solutions did not show any significant differences among the results. For the southern solar orientation, the minimum energy consumption was achieved with the use of passive solutions.

Figure 24. Funchal-Madeira: Heating Energy Needs. Conventional System (a) and LGSF System (b).

For the LGSF system envelope and comparing the results of energy heating needs for Funchal average decreases of $19 \%$ and $28 \%$ were observed with the use of glazing 04 and one Trombe wall and glazing 04 and two Trombe walls, respectively. Taking into account that the use of glazing 07 
promotes a greater decrease in the energy consumption in the model, average decreases of $8 \%$ and $13 \%$ in the energy heating needs were achieved with the use of glazing 07 and one Trombe wall and glazing 07 and two Trombe walls, respectively. For the conventional system envelope and comparing the results of energy heating needs for Funchal, average decreases of $15 \%$ and $25 \%$ were observed with the use of glazing 04 and one Trombe wall and glazing 04 and two Trombe walls, respectively. An average decrease of $9 \%$ in the energy heating needs for both glazing 07 and one Trombe wall and two Trombe walls was observed.

\subsection{Daylighting Performance}

Both daylight factor and illumination level values were compared with those provided by Goulding et al. (1994) [36], A Green Vitruvius (1999) [37] and CIBSE (1999) [38] for residential buildings. The illuminance levels were compared with the values indicated by Goulding et al. (1994) [36] and CIBSE (2002) [39]. The results of simulations were compared with the transmittance curve of the glazings analyzed (visible transmittance), which showed a direct relation with the daylighting performance in the visible region. The objective was to obtain daylight factor and illuminance levels according to the values indicated for residential buildings. An energy saving with the use of a glazed area and Trombe wall was obtained only in Design Builder thermal simulations.

The results provided by Ecotect software are consistent, taking into account the similarity between the values and those recommended, for both daylight factor and illuminance levels. The values for the DF and level of illuminance showed a good approximation to the one recommended by the literature, therefore our results are consistent with a real situation.

\subsubsection{Lisbon}

Figures 25 and 26 show charts of daylight factor (DF) and illuminance levels. Table 11 shows the values for a horizontal plan $(0,8 \mathrm{~m})$ of the simulated room. The daylight factor values were obtained from Ecotect 5.6. A higher average of illuminance level was obtained using glazing 07. Glazing 04 showed lower daylighting performance.

Table 11. Lisbon: Daylight Factor and Illuminance Level. 
Regarding to the average of the illuminance levels for overcast skies, the values were not in agreement with those recommended for kitchens. However, higher illumination levels could be obtained near the glazing. The daylight factor found proved that the glazing form and dimensions provided the values recommended for all verified areas.

Figure 25. Lisbon - Glazing 04: Daylight Factor (a) and Illuminance Level (b)

Figure 26. Lisbon - Glazing 07: Daylight Factor (a) and Illuminance Level (b).

\subsubsection{Oporto}

Figures 27 and 28 show charts of daylight factor (DF) and illuminance levels. Table 12 shows the values obtained on a horizontal plan $(0,8 \mathrm{~m})$ of the simulated room. Again, a higher average of illuminance level was achieved with the use of glazing 07 whereas the lower values were obtained by using glazing 04 .

Table 12. Oporto: Daylight Factor and Illuminance Level

Concerning the average of the illuminance levels for overcast skies, the values were not in agreement with those recommended for any room that used glazing 04 . The illuminance level of glazing 07 is not adequate for kitchens. However, higher illumination levels can be obtained near the glazing. The daylight factor found proved that the glazing form and dimensions provided the values recommended for all verified areas.

Figure 27. Oporto: Glazing 04 - Daylight Factor (a) and Illuminance Level (b).

Figure 28. Oporto: Glazing 07 - Daylight Factor (a) and Illuminance Level (b).

\subsubsection{Lajes - Azores}

The daylight factor (DF) and illuminance levels are shown in Figures 29 and 30. Table 13 shows the values obtained on a horizontal plan of the simulated room for Lajes (Azores) latitude.

Table 13. Lajes - Azores: Daylight Factor and Illuminance Level

The average of illuminance levels for overcast skies was not in agreement with the values recommended for kitchens. The daylight factor found proved that the glazing form and dimensions 
provided the values recommended for all verified areas. A higher average of illuminance level was obtained using glazing 07.

Figure 29. Lajes-Azores: Glazing 04 - Daylight Factor (a) and Illuminance Level(b).

\subsubsection{Funchal - Madeira}

Figure 30. Lajes-Azores: Glazing 07 - Daylight Factor (a) and Illuminance Level (b).

Figures 31 and 32 show charts of daylight factor (DF) and illuminance levels. A higher average of illuminance level was obtained with the use of glazing 07 in the façade. Glazing 04 showed lower daylighting performance (Table 14).

Figure 31. Funchal-Madeira: Glazing 04 - Daylight Factor (a) and Illuminance Level (b). Figure 32. Funchal-Madeira: Glazing 07 - Daylight Factor (a) and Illuminance Level (b). Table 14. Funchal - Madeira: Daylight Factor and Illuminance Level

The average values of the illuminance levels for overcast skies were not in agreement with those recommended for kitchens. However, higher illumination levels could be obtained near the glazing. The daylight factor found proved that the glazing form and dimensions provided the values recommended for all verified areas.

\subsubsection{Comparison Between Transmitance Curve and Daylighting Performance}

The glazing spectral transmittance curve was obtained by means of spectrophotometer tests and the results showed a direct relation with the daylight performance in the visible region and the thermal performance in the infrared region. A decrease was observed in the visible transmittance for glazing 04 constituted by a green glass solar control (outer pane) and a low-e glass (inner pane). Glazing 04 (Cool Lite KNT 155 Green - air - Planitherm Futur Ultra N) showed 25.15\% visible transmittance and glazing 07 (Bioclean - air - Planilux) showed 70,34\% visible transmittance, ensuring a high level of daylighting (Figure 33).

Figure 33. Glazing Transmittance Curves. 


\section{DISCUSSION}

\subsection{Thermal Performance}

The results show that the heating energy needs resulting from the use of all types of façade were lower than the maximum limits allowed, according to the Portuguese energy building performance regulation RCCTE. In this case, façades with Glazing 07 with one or two Trombe walls showed the smallest heating energy need in comparison with the others. The heating energy needs were similar for both envelopes analyzed. For milder climates, as in Lisbon, Lajes and Funchal, the use of one or two Trombe walls showed identical results; therefore the second Trombe is not necessary to achieve the same level of energy savings. For all climates, the southern solar orientation showed the minimum energy consumption with the integration of passive solutions.

According to RCCTE, the period in months of the heating season is 5.3 for Lisbon, 6.7 for Porto, 4.0 for Lajes and 3.89 for Funchal, meaning that, per year, only during those months heating is necessary to maintain indoor comfortable conditions.

However, it is also very important to consider the cooling energy needs, although they are not presented in this study. As an example, Lisbon shows the highest values of cooling needs based on RCCTE for the simulated model. Therefore, the best performance solutions in the heating energy needs caused a $16-40 \%$ (on 32kWh/m².year) energy consumption increase in the cooling needs. Such an increase can be reduced by using shading systems during the summer (this module is foreseen in the façade system developed).

Thermal simulations results could be compared with transmittance results because the infrared transmittance, besides other factors, is directly related to the thermal performance of the glazing. The infrared transmittance of Glazing 04 was lower than that of Glazing 07, ensuring a high level of thermal performance for glazing 07.

\subsection{Daylighting Performance}

A better daylighting performance was observed for Glazing 07 . The spectral transmittance curve validated the daylight simulations and confirmed the results of computational simulations. The glazing transmittance curves confirmed the better performance observed when Glazing 07 was used in the computer simulations conducted on Ecotect 5.6 and Desktop Radiance. 


\section{CONCLUSIONS}

Energy simulations for two glazing types and Trombe walls for four Portuguese climates were conducted to evaluate the thermal and daylight performance of glazings. They showed how the integration of the proposed passive solutions and glazing in the façades system could reduce the energy consumption with heating systems and improve the daylighting quality of the buildings.

Better thermal and daylighting performances were achieved for the same glazing (Glazing 07). The spectral transmittance curve validated the daylight simulations and confirmed the results. The visible transmittance (for daylighting) and the infrared transmittance (for thermal performance) were important aspects for the choice of a better glazing based on the climate and architectural typology. Other features, such as solar factor (or g-value), solar heat gain coefficient, shading coefficient, transmittance, and U-factor must also be taken into account.

The integration of passive heating solutions and the adequate choice of glazing in the façade modules seem to be the ideal strategy for a better thermal and daylighting performance, decreasing the energy needs.

\section{ACKNOWLEDGEMENTS}

The authors gratefully acknowledge the financial support provided by Erasmus Mundus ISAC Improving Skills Across Continents for this research.

\section{REFERENCES}

[1] Castrillón. R. D'a. Integration of Active and Passive Systems in Glass Façades. Technische Universität Berlin, Berlin, Germany. In: International Conference on Sustainable Energy Technologies, 8. Aachen. Germany: August 31st to 3rd September, 2009.

[2] Morse, E. L. Warming and Ventilating Apartments by Sun's Rays. U. S. Patent 246,626, 1881.

[3] Trombe, F. US Patent 3,832,992, 1972.

[4] Torcellini, P.; Pless, S. Trombe Walls in Low-Energy Buildings: Practical Experiences. Preprint. 8 pp.; NREL Report No. CP-550-36277, 2004.

[5] Sun, W.; Ji, J.; Luo, C.; He, W. Performance of PV-Trombe wall in winter correlated with south façade design. Applied Energy, Vol. 88, Issue 1, January 2011, Pages 224-231.

[6] Balcomb, J. D. Introduction, Passive Solar Buildings, Balcomb, J. D. (ed.), pp. 1-37. Cambridge, MA: The MIT Press. 1992. 
[7] Sadineni, S. B.; Madala, S.; Boehm, R. F. Passive building energy savings: A review of building envelope components. Renewable and Sustainable Energy Reviews. Vol.15, Issue 8. October, 2011.

[8] Zalewski L, Lassue S, Duthoit B, Butez M. Study of solar walls-validating a simulation model. Building and Environment, Vol. 37, Issue 1. January, 2002.

[9] Jie J, Hua Y, Wei H, Gang P, Jianping L, Bin J. Modeling of a novel Trombe wall with PV cells. Building and Environment, Vol. 42, Issue 3, March, 2007.

[10] Tyagi VV, Buddhi D. PCM thermal storage in buildings: a state of art. Renewable and Sustainable Energy Reviews. Vol. 11, Issue 6. August, 2007.

[11] Gonçalves H.; Oliveira M.; Patricio A.; Cabrito P. Passive Solar Buildings in Portugal: Experiences in the Last 20 years. Department of Renewable Energies - INETI Instituto Nacional de Engenharia, Tecnologia e Inovação, 1997.

[12] Ellis, P. G. Development and validation of the unvented trombe wall model in Energyplus. [on line]. Master of Science in Mechanical Engineering, University of Illinois at Urbana-Champaign. Urbana, Illinois, 2003. [Consult. 05 Mar. 2013]. Available in: http://apps1.eere.energy.gov/buildings/energyplus/pdfs/bibliography/ellis_thesis_2003.pdf

[13] Ebbert, T.; Knaack, U. A flexible and upgradeable fafade concept for refurbishment. In: SB07 Lisbon - Sustainable Construction, Materials and Practices: Challenge of the Industry for the New Millenium, 2008.

[14] Treberspurg, M., Djalili, M. New technical solutions for energy efficient buildings. State-of-the art Report Multifunctional façade systems. SCI - Network Sustainable Construction \& Innovation through Procurement. October, 2010.

[15] Wicona. Productos y Referencias: Temotion. [on line]. 2009. [Consult. 05 Mar. 2013] Available in: http://www.wicona.es/descargas/archivos/Wicona\%20-\%20no\%20limits.pdf

[16] Sacht, H. M.; Bragança, L.; Almeida, M. Façades Modules for Eco-Efficient Refurbishment of Buildings: An Overview. In: Portugal SB10 - Sustainable Building Affordable to All, 10. Algarve, 2010.

[17] Sacht, H. M.; Bragança, L.; Almeida, M. Façades Modules for Eco-Efficient Refurbishment of Buildings: Glazing Thermal Performance Analyses to Coimbra and Faro. In: 3rd PALENC 2010 - XIII Passive \& Low Energy Cooling for the Built Environment. Rhodes Island, Greece 2010.

[18] Sacht, H. M.; Bragança, L.; Almeida, M.; Caram, R. Trombe Wall Thermal Performance for a Modular Façade System in different Portuguese Climates: Lisbon, Porto, Lajes and Funchal. In: Building Simulation 2011. Sydney, 2011.

[19] Regulamento das Características do Comportamento Térmico dos Edifícios (RCCTE). Decreto-Lei n. ํ 80/2006: Diário da República - Série I-A no. 67. Lisboa: 4 de Abril, 2006.

[20] DesignBuilder Software. DesignBuilder 1.5. User Manual. March, 2008.

[21] American Society of Heating, Refrigerating and Air Conditioning Engineers (ANSI/ASHRAE) 
Standard 140-2007 Building Thermal Envelope and Fabric Load Tests DesignBuilder Version 2.1.0 (incorporating EnergyPlus version 4.0.0) - Report, Jan 2010.

[22] Gard Analytics, EnergyPlus Testing with Building Thermal Envelope and Fabric Load Tests from ANSI/ASHRAE Standard 140-2007. October, 2009.

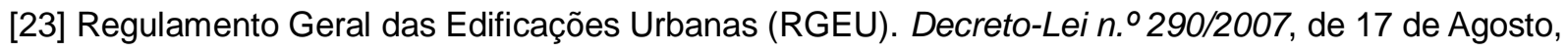
2007.

[24] Santos, P.; Gervásio, H.; Simões da Silva, L.; Lopes, A.M.G. Influence of climate change on the energy efficiency of light steel residential buildings. Civil Engineering and Environmental Systems. vol. 28, n누, pp. 325-352, 2011.

[25] Lawrence Berkeley National Laboratory (LBNL). Window 6.2.33.0. [on line]. [Consult. 05 Mar. 2013]. Available in: http://windows.lbl.gov/software/window/window.html

[26] Sousa. O. J. S. Obtenção dos perfis de utilização, iluminação e de equipamentos das habitações residenciais. Relatório de Projecto Individual. Universidade do Minho, 2008.

[27] American Society of Heating, Refrigerating and Air Conditioning Engineers (ASHRAE). Fundamentals Handbook. American Society of Heating, Ventilating and Air-Conditioning Engineers. Atlanta. USA, 2005.

[28] Santos, A. J. Desenvolvimento de uma metodologia de caracterização das condições de iluminação natural nos edifícios baseada na avaliação in situ. Dissertação de Mestrado. Faculdade de Lisboa. Lisboa, 2001.

[29] Cardoso, C. J. L. Desenvolvimento da janela eco eficiente. Dissertação de Mestrado em Engenharia Civil - Gestão, Tecnologia e Física das Construções, Universidade do Minho. Guimarães, 2008.

[30] Autodesk Ecotect Analysis. Autodesk Ecotect Analysis, 2011. [on line]. [Consult. 05 Mar. 2013] Available in: http://usa.autodesk.com/ecotect-analysis/

[31] AUTODESK. Validation of Ecotect Analysis Results. 2012. [on line]. [Consult. 05 Mar. 2013]. Available

http://usa.autodesk.com/adsk/servlet/ps/dl/item?sitelD=123112\&id=14576143\&linkID=13734494

[32] Altan, H., Ward, I., Mohelnikova, J., Vajkay, F. An internal assessment of the thermal comfort and daylighting conditions of a naturally ventilated building with an active glazed façade in a temperate climate. Energy and Buildings, Vol. 41, Issue 1. January, 2009.

[33] Ibarra, D.; Reinhart, C. Daylight factor simulations - how close do simulation beginners 'really' get? In: Building Simulation 2009. Glasgow, Scotland, 2009.

[34] Krüger, E. L.; Dorigo, A. L. Daylighting analysis in a public school in Curitiba, Brazil Technical Note. Renewable Energy, n. 33, 2008. 1695-1702pp.

[35] Mistrick, R. G. Desktop Radiance Overview. [on line]. [Consult. 05 Mar. 2013]. Pennsylvania State University, 2000. Available in: http://radsite.lbl.gov/deskrad/drad-overview.pdf 
[36] Goulding, J. R., Lewis, J. O, Steemers, T. C. (ed.). Energy in Architecture. The European Passive Solar Handbook. Batsford for the Comission of the European Communities. London, 1994.

[37] A Green Vitruvius. Principles and Practice of Sustainable Architectural Design. Edited by J.Owen Lewis. James \& James: London, 1999.

[38] Chartered Institution Of Building Services Engineers (CIBSE). Daylighting and window design. Lighting Guide LG10. The Chartered Institution of Building Services Engineers. London, UK, 1999.

[39] Chartered Institution Of Building Services Engineers (CIBSE). Code for Lighting Part 2, 2002.

[40] Caram, R. M. Estudo e Caracterização de Fachadas Transparentes para Uso na Arquitetura: Ênfase na Eficiência Energética. Tese de Livre-Docência - Departamento de Arquitetura e Urbanismo Escola de Engenharia de São Carlos- EESC/ USP. São Carlos. 2002.

[41] Caram, R. M. Caracterização Ótica de Materiais Transparentes e sua Relação com o Conforto Ambiental em Edificações. Tese (Doutorado em Engenharia Civil) - Faculdade de Engenharia Civil, Universidade Estadual de Campinas-UNICAMP. Campinas. 1998.

[42] Sacht, H. M. Módulos de Fachada para Reabilitação Eco-Eficiente de Edifícios. Tese (Doutorado em Engenharia Civil) - Departamento de Engenharia Civil, Universidade do Minho. Portugal, Guimarães, 2013. 


\section{LIST OF TABLE CAPTIONS}

Table 1. Climates for Computational Simulations

Table 2. Overall Heat Transfer Coefficient $\left(\mathrm{W} / \mathrm{m}^{2}{ }^{\circ} \mathrm{C}\right)$

Table 3. Types of glass for the standard module.

Table 4. Glazing Properties.

Table 5. Internal Gains $\left(\mathrm{W} / \mathrm{m}^{2}\right)$

Table 6. Façade Settings for Daylighting Performance Simulations.

Table 7. Reflectance of Materials

Table 8. Daylight Factor for Residential Buildings.

Table 9. Illuminance by Location.

Table 10. Illuminance Level: Residential buildings

Table 11. Lisbon: Daylight Factor and Illuminance Level.

Table 12. Oporto: Daylight Factor and Illuminance Level

Table 13. Lajes - Azores: Daylight Factor and Illuminance Level

Table 14. Funchal - Madeira: Daylight Factor and Illuminance Level 
Table 1. Climates for Computational Simulations

\begin{tabular}{|c|c|c|c|c|c|c|}
\hline \multirow{2}{*}{ Climates } & \multicolumn{2}{|c|}{ Climatic Zone } & \multicolumn{2}{|c|}{ Energy Needs } & \multirow{2}{*}{$\begin{array}{l}\text { Duration of } \\
\text { Winter } \\
\text { (months) }\end{array}$} & \multirow{2}{*}{$\begin{array}{c}\text { Degree } \\
\text { Days } \\
\text { (듬 } \\
\text { ( D ) }\end{array}$} \\
\hline & Winter & Summer & $\begin{array}{c}\text { Heating } \\
\left(\mathrm{kWh} / \mathrm{m}^{2} \text {.year }\right)\end{array}$ & $\begin{array}{c}\text { Cooling } \\
\text { (kWh/m².year) }\end{array}$ & & \\
\hline Lisbon & 11 & V2 & 56.36 & 32.00 & 5.30 & 1190 \\
\hline Oporto & 12 & V1 & 74.66 & 16.00 & 6.70 & 1610 \\
\hline Lajes - Azores & 11 & V1 & 36.42 & 21.00 & 4.00 & 732.5 \\
\hline Funchal - Madeira & 11 & V1 & 46.42 & 23.00 & 3.89 & 962 \\
\hline
\end{tabular}

Table 2. Overall Heat Transfer Coefficient $\left(\mathrm{W} / \mathrm{m}^{2}{ }^{\circ} \mathrm{C}\right)$

\begin{tabular}{c|c|c}
\hline \multicolumn{2}{|c}{ Heat Transfer Coefficient $\left(\mathbf{W} / \mathbf{m}^{2}{ }^{\circ} \mathrm{C}\right)$} \\
\hline \multirow{2}{*}{ Element-Envelope } & \multicolumn{2}{|c}{ Portuguese Conventional System } \\
\cline { 2 - 3 } & Total Thickness $(\mathrm{cm})$ & $\mathrm{U}\left(\mathrm{W} / \mathrm{m}^{20} \mathrm{C}\right)$ \\
\hline External Walls & 0.365 & 0.46 \\
\hline Roof Slab & 0.280 & 0.55 \\
\hline \multirow{2}{*}{ Element-Envelope } & Light Gauge Steel Framing System \\
\cline { 2 - 3 } & Total Thickness $(\mathrm{cm})$ & $\mathrm{U}\left(\mathrm{W} / \mathrm{m}^{20} \mathrm{C}\right)$ \\
\hline External Walls & 0.200 & 0.14 \\
\hline Roof Slab & 0.333 & 0.22 \\
\hline
\end{tabular}

Table 3. Types of glass for the standard module.

\begin{tabular}{l|c|c|c|c|c}
\hline \multicolumn{7}{c|}{ Properties } & $\begin{array}{c}\text { Cool Lite } \\
\text { KNT 155 } \\
\text { Green }\end{array}$ & Bioclean & Planilux & $\begin{array}{c}\text { Planitherm } \\
\text { Futur Ultra N }\end{array}$ & Diamant \\
\hline Thickness $(\mathrm{mm})$ & $4 \mathrm{~mm}$ & $4 \mathrm{~mm}$ & $4 \mathrm{~mm}$ & $4 \mathrm{~mm}$ & $4 \mathrm{~mm}$ \\
\hline Solar Factor & 0.45 & 0.84 & 0.85 & 0.63 & 0.90 \\
\hline Shading Coefficient & 0.52 & 0.97 & 0.98 & 0.72 & 1.04 \\
\hline Visible Transmittance & 0.47 & 0.87 & 0.90 & 0.88 & 0.91 \\
\hline $\mathrm{U}\left(\mathrm{W} / \mathrm{m}^{2} \mathrm{~K}\right)$ & 5.75 & 5.87 & 5.80 & 5.73 & 5.80 \\
\hline
\end{tabular}

Table 4. Glazing Properties.

\begin{tabular}{l|c|c|c}
\hline \multirow{2}{*}{\multicolumn{1}{c|}{ Properties }} & \multicolumn{3}{|c}{ Glazing } \\
\cline { 2 - 4 } & Glazing 04 & Glazing 07 & Trombe Glazing \\
\hline \multirow{2}{*}{ Outermost Pane } & $\begin{array}{c}\text { Cool Lite KNT 155 } \\
\text { Green 4mm }\end{array}$ & $\begin{array}{c}\text { Bioclean } \\
4 \mathrm{~mm}\end{array}$ & $\begin{array}{c}\text { Diamant } \\
4 \mathrm{~mm}\end{array}$ \\
\hline Inner Pane & $\begin{array}{c}\text { Planitherm Futur } \\
\text { Ultra N 4mm }\end{array}$ & $\begin{array}{c}\text { Planilux } \\
4 \mathrm{~mm}\end{array}$ & $\begin{array}{c}\text { Diamant } \\
4 \mathrm{~mm}\end{array}$ \\
\hline $\mathrm{U}\left(\mathrm{W} / \mathrm{m}^{2} \mathrm{~K}\right)$ & 1.66 & 2.69 & 2.72 \\
\hline Solar Factor & 0.28 & 0.40 & 0.83 \\
\hline Shading Coefficient & 0.33 & 0.46 & 0.95 \\
\hline Visible Transmittance $(\%)$ & 0.42 & 0.71 & 0.84 \\
\hline Relative Heat Gain $\left(\mathrm{W} / \mathrm{m}^{2}\right)$ & 217.72 & 311.28 & 622.90 \\
\hline
\end{tabular}


Table 5. Internal Gains $\left(\mathrm{W} / \mathrm{m}^{2}\right)$

\begin{tabular}{llll}
\hline \multicolumn{1}{c}{ Internal Gains } & \multicolumn{1}{c}{ Values $\left(\mathrm{W} / \mathrm{m}^{2}\right)$} & \multicolumn{3}{c}{ Details } \\
\hline Occupation & $5,6 \mathrm{~W} / \mathrm{m}^{2}(2$ people $)$ & $70 \mathrm{~W}$ per person & \\
\hline \multirow{3}{*}{ Lighting } & & Illuminance $\quad$ (incidence): & $300 \mathrm{lux} ;$ \\
& $9,4 \mathrm{~W} / \mathrm{m}^{2}$ & Fluorescent lamp $(40 \mathrm{~W}) ; \quad$ Efficiency \\
& & $80 \mathrm{Im} / \mathrm{W}(40 \%$ delivery efficiency). \\
\hline Equipment & $8 \mathrm{~W} / \mathrm{m}^{2}$ & Equipment potency: $200 \mathrm{~W}$. & \\
\hline
\end{tabular}

Table 6. Façade Settings for Daylighting Performance Simulations.

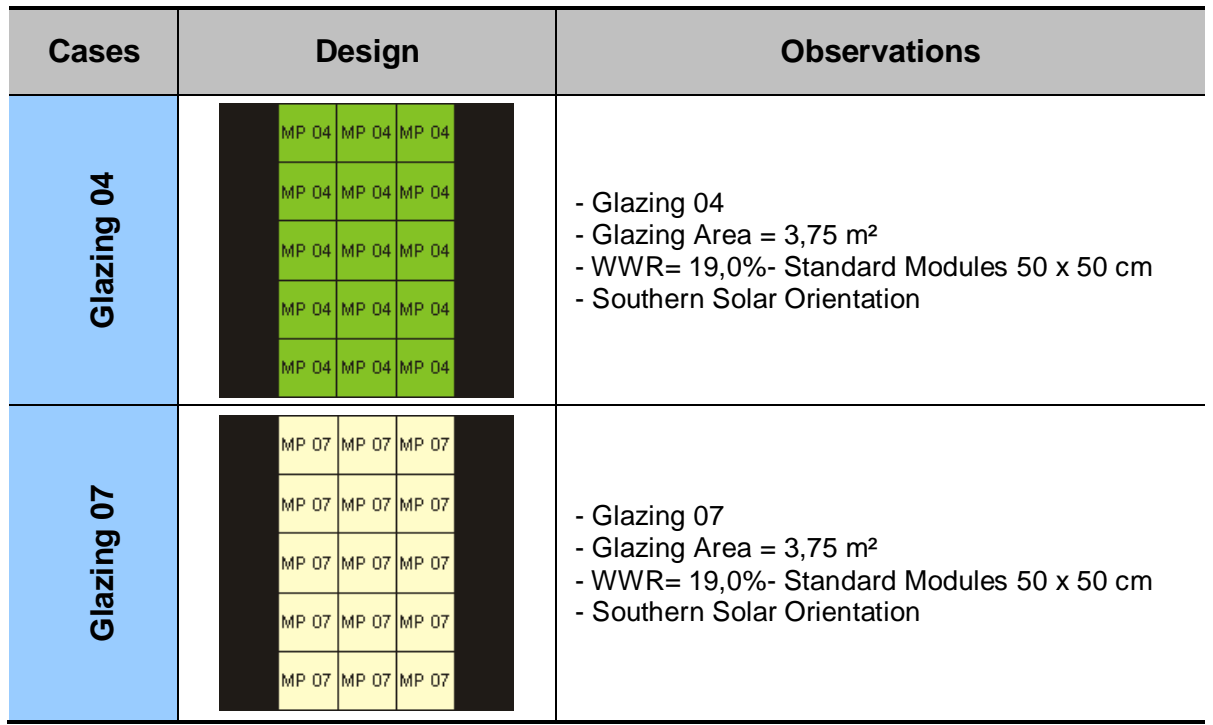

Table 7. Reflectance of Materials

\begin{tabular}{l|c|c|c|c|c}
\hline $\begin{array}{c}\text { Opaque } \\
\text { Surface }\end{array}$ & Color & Texture & Cleaning & Reflectance & $\begin{array}{c}\text { Recommended } \\
\text { (SANTOS, 2001) }\end{array}$ \\
\hline Walls-Inside & White & smooth plaster - mate & clean & 0,6 & $0,60-0,70$ \\
\hline Walls-Outside & White & smooth plaster - mate & clean & 0,7 & - \\
\hline Ceiling-Inside & White & smooth plaster - mate & clean & 0,7 & $0,70-0,85$ \\
\hline Ceiling -Outside & Light Brown & smooth mortar - mate & clean & 0,3 & - \\
\hline Floor & Light Brown & smooth mortar - mate & clean & 0,3 & $0,15-0,30$ \\
\hline
\end{tabular}

Table 8. Daylight Factor for Residential Buildings.

\section{Daylight Factor: Residential Buildings}

\begin{tabular}{l|c|c|c|c|c}
\hline \multirow{2}{*}{ Room } & \multirow{2}{*}{ Goulding et al. (1994) [36] } & \multicolumn{2}{|c|}{ A Green Vitruvius (1999) [37] } & \multicolumn{2}{c}{ CIBSE (1999) [38] } \\
\cline { 3 - 6 } & & Minimum & Average & Minimum & Average \\
\hline Bedroom & $0.5 \%$ (3/4 of room length) & $0.3 \%$ & $1 \%$ & $0.3 \%$ & $1 \%$ \\
\hline Kitchen & $2 \%$ (center) & $0.6 \%$ & $2 \%$ & $0.6 \%$ & $2 \%$ \\
\hline Living Room & $1 \%$ (center) & $0.5 \%$ & $1.5 \%$ & $0.5 \%$ & $1.5 \%$ \\
\hline
\end{tabular}


Table 9. Illuminance by Location.

\begin{tabular}{l|c}
\hline \multicolumn{1}{c}{ Location } & Cities \\
\hline Lisbon & 7000 \\
\hline Oporto & 6500 \\
\hline Lajes-Azores & 7000 \\
\hline Funchal-Madeira & 8500 \\
\hline
\end{tabular}

Table 10. Illuminance Level: Residential buildings

\begin{tabular}{lc|c}
\hline \multicolumn{3}{c}{ Illuminance Level: Residential buildings } \\
\hline \multicolumn{1}{c}{ Room } & Goulding et al. (1994) [36] & CIBSE (2002) [39] \\
\hline Hallway & $50-100$ & - \\
\hline Bedroom & - & - \\
\hline Living room & 200 & $100-300$ \\
\hline Dining room & 100 & $100-300$ \\
\hline Kitchen & 200 & $150-300$ \\
\hline
\end{tabular}

Table 11. Lisbon: Daylight Factor and Illuminance Level.

\begin{tabular}{c|c|c|c|c}
\hline \multirow{2}{*}{ Façades } & \multirow{2}{*}{ DF (\%) } & \multicolumn{3}{|c}{ Verification of DF (\%) } \\
\cline { 3 - 5 } & & $\begin{array}{c}\text { Bedrooms } \\
0.3 \% \text { a } 1 \%\end{array}$ & $\begin{array}{c}\text { Living Rooms } \\
0.5 \% \text { a } 1.5 \%\end{array}$ & $\begin{array}{c}\text { Kitchens } \\
0.6 \% \text { a } 2 \%\end{array}$ \\
\hline Glazing $04_{19,0 \%}$ & 2,58 & OK & OK & OK \\
\hline Glazing $07_{19,0 \%}$ & 4,04 & OK & OK & OK \\
\hline \multirow{2}{*}{ Façades } & Illuminance & \multicolumn{2}{|c}{ Verification of Illuminance Level (Lux) } \\
\cline { 3 - 5 } & Level (Lux) & $\begin{array}{c}\text { Bedrooms } \\
100-200 \text { lux }\end{array}$ & $\begin{array}{c}\text { Living Rooms } \\
100-300 \text { lux }\end{array}$ & $\begin{array}{c}\text { Kitchens } \\
150-300 \text { lux }\end{array}$ \\
\hline Glazing 04 $19,0 \%$ & 101,45 & OK & OK & - \\
\hline Glazing 07 $19,0 \%$ & 111,86 & OK & OK & - \\
\hline
\end{tabular}

Table 12. Oporto: Daylight Factor and Illuminance Level

\begin{tabular}{|c|c|c|c|c|}
\hline \multirow[b]{2}{*}{ Façades } & \multirow[b]{2}{*}{ DF (\%) } & \multicolumn{3}{|c|}{ Verification of DF(\%) } \\
\hline & & $\begin{array}{l}\text { Bedrooms } \\
0.3 \% \text { a } 1 \%\end{array}$ & $\begin{array}{c}\text { Living Rooms } \\
0.5 \% \text { a } 1.5 \%\end{array}$ & $\begin{array}{c}\text { Kitchens } \\
0.6 \% \text { a } 2 \%\end{array}$ \\
\hline Glazing $04_{19,0 \%}$ & 2,68 & OK & OK & OK \\
\hline Glazing $07_{19,0 \%}$ & 4,14 & OK & OK & OK \\
\hline \multirow{2}{*}{ Façades } & \multirow{2}{*}{$\begin{array}{l}\text { Illuminance } \\
\text { Level (Lux) }\end{array}$} & \multicolumn{3}{|c|}{ Verification of Illuminance Level (Lux) } \\
\hline & & $\begin{array}{l}\text { Bedrooms } \\
100-200 \text { lux }\end{array}$ & $\begin{array}{c}\text { Living Rooms } \\
100-300 \text { lux }\end{array}$ & $\begin{array}{c}\text { Kitchens } \\
150-300 \text { lux }\end{array}$ \\
\hline Glazing 04 19,0\% & 94,24 & - & - & - \\
\hline Glazing $07_{19,0 \%}$ & 103,86 & $\mathrm{OK}$ & $\mathrm{OK}$ & - \\
\hline
\end{tabular}


Table 13. Lajes - Azores: Daylight Factor and Illuminance Level

\begin{tabular}{|c|c|c|c|c|}
\hline \multirow[b]{2}{*}{ Façades } & \multirow[b]{2}{*}{ DF (\%) } & \multicolumn{3}{|c|}{ Verification of DF (\%) } \\
\hline & & $\begin{array}{l}\text { Bedrooms } \\
0.3 \% \text { a } 1 \%\end{array}$ & $\begin{array}{c}\text { Living Rooms } \\
0.5 \% \text { a } 1.5 \% \\
\end{array}$ & $\begin{array}{c}\text { Kitchens } \\
0.6 \% \text { a } 2 \% \\
\end{array}$ \\
\hline Glazing $04_{19,0 \%}$ & 2,61 & $\mathrm{OK}$ & OK & $\mathrm{OK}$ \\
\hline Glazing $07_{19,0 \%}$ & 4,15 & OK & $\mathrm{OK}$ & OK \\
\hline \multirow[b]{2}{*}{ Façades } & \multirow{2}{*}{$\begin{array}{l}\text { Illuminance } \\
\text { Level (Lux) }\end{array}$} & \multicolumn{3}{|c|}{ Verification of Illuminance Level (Lux) } \\
\hline & & $\begin{array}{c}\text { Bedrooms } \\
100-200 \text { lux }\end{array}$ & $\begin{array}{c}\text { Living Rooms } \\
100-300 \text { lux }\end{array}$ & $\begin{array}{c}\text { Kitchens } \\
150-300 \text { lux }\end{array}$ \\
\hline Glazing $04_{19,0 \%}$ & 101,45 & $\mathrm{OK}$ & $\mathrm{OK}$ & - \\
\hline Glazing $07_{19,0 \%}$ & 111,86 & OK & OK & - \\
\hline
\end{tabular}

Table 14. Funchal - Madeira: Daylight Factor and Illuminance Level

\begin{tabular}{|c|c|c|c|c|}
\hline \multirow[b]{2}{*}{ Façades } & \multirow[b]{2}{*}{ DF (\%) } & \multicolumn{3}{|c|}{ Verification of DF(\%) } \\
\hline & & $\begin{array}{l}\text { Bedrooms } \\
0.3 \% \text { a } 1 \%\end{array}$ & $\begin{array}{c}\text { Living Rooms } \\
0.5 \% \text { a } 1.5 \%\end{array}$ & $\begin{array}{c}\text { Kitchens } \\
0.6 \% \text { a } 2 \%\end{array}$ \\
\hline Glazing 04 19,0\% & 2,54 & OK & $\mathrm{OK}$ & OK \\
\hline Glazing $07_{19,0 \%}$ & 4,15 & $\mathrm{OK}$ & $\mathrm{OK}$ & $\mathrm{OK}$ \\
\hline \multirow[b]{2}{*}{ Façades } & \multirow{2}{*}{$\begin{array}{l}\text { Illuminance } \\
\text { Level (Lux) }\end{array}$} & \multicolumn{3}{|c|}{ Verification of Illuminance Level (Lux) } \\
\hline & & $\begin{array}{c}\text { Bedrooms } \\
100-200 \text { lux }\end{array}$ & $\begin{array}{c}\text { Living Rooms } \\
100-300 \text { lux }\end{array}$ & $\begin{array}{c}\text { Kitchens } \\
150-300 \text { lux }\end{array}$ \\
\hline Glazing $04_{19,0 \%}$ & 123,23 & $\mathrm{OK}$ & $\mathrm{OK}$ & - \\
\hline Glazing $07_{19.0 \%}$ & 135,83 & OK & $\mathrm{OK}$ & - \\
\hline
\end{tabular}




\section{LIST OF FIGURE CAPTIONS}

Figure 1. ". Vale Rosal Building (Charneca da Caparica-Lisbon).

Figure 2. Schäfer Residence (Porto Santo-Madeira).

Figure 3. Nursery (Mertola)

Figure 4. Internal I modul-Façade Panels.

Figure 5. Temotion Façade.

Figure 6. Capricorn Façade.

Figure 7. Main idea of the modular façade system.

Figure 8. Main screen of DesignBuilder software.

Figure 9. Model: One Trombe wall.

Figure 10. Model: Two Trombe walls.

Figure 11. Portuguese Conventional System: Roof Slab.

Figure 12. Portuguese Conventional System: Wall.

Figure 13. Light Gauge Steel Framing System: Roof Slab.

Figure 14. Light Gauge Steel Framing System: Wall.

Figure 15. Occupation Schedule.

Figure 16. Lighting Schedule.

Figure 17. Equipment Schedule.

Figure 18. Ventilation Schedule.

Figure 19. Ecotect Main Screen.

Figure 20. Conditions of Daylighting Simulation: 3D Illustrative diagrams (a) (b).

Figure 21. Lisbon: Heating Energy Needs. Conventional System (a) and LGSF System (b).

Figure 22. Oporto: Heating Energy Needs. Conventional System (a) and LGSF System (b).

Figure 23. Lajes-Azores: Heating Energy Needs. Conventional System (a) and LGSF System (b).

Figure 24. Funchal-Madeira: Heating Energy Needs. Conventional System (a) and LGSF System (b).

Figure 25. Lisbon - Glazing 04: Daylight Factor (a) and Illuminance Level (b)

Figure 26. Lisbon - Glazing 07: Daylight Factor (a) and Illuminance Level (b).

Figure 27. Oporto: Glazing 04 - Daylight Factor (a) and Illuminance Level(b).

Figure 28. Oporto: Glazing 07 - Daylight Factor (a) and Illuminance Level(b).

Figure 29. Lajes-Azores: Glazing 04 - Daylight Factor (a) and Illuminance Level(b). 
Figure 30. Lajes-Azores: Glazing 07 - Daylight Factor (a) and Illuminance Level(b).

Figure 31. Funchal-Madeira: Glazing 04 - Daylight Factor (a) and Illuminance Level (b).

Figure 32. Funchal-Madeira: Glazing 07 - Daylight Factor (a) and Illuminance Level(b).

Figure 33. Glazing Transmittance Curves.

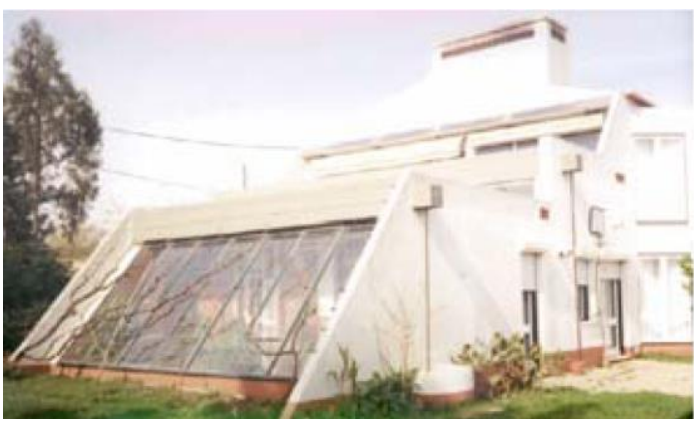

Figure 1. ". Vale Rosal Building (Charneca da Caparica-Lisbon).

Reference: Gonçalves et al., 1997 [7].

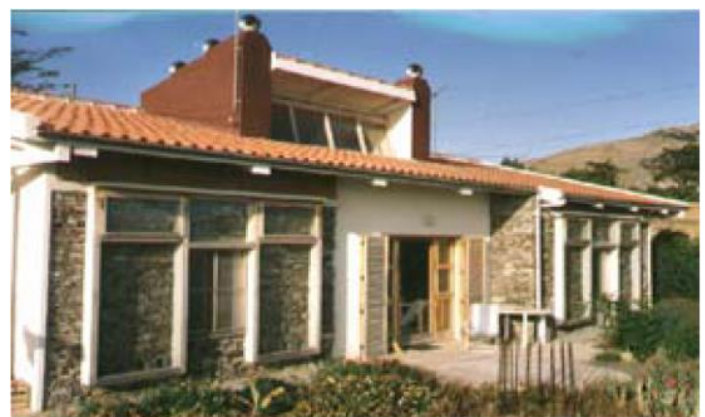

Figure 2. Schäfer Residence (Porto SantoMadeira).

Reference: Gonçalves et al., 1997 [7].

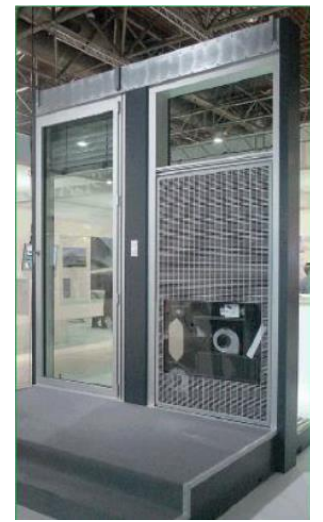

Figure 4. Internal modul-Façade

Panels.

Reference:Treberspu rg; Djalili (2010) [14].

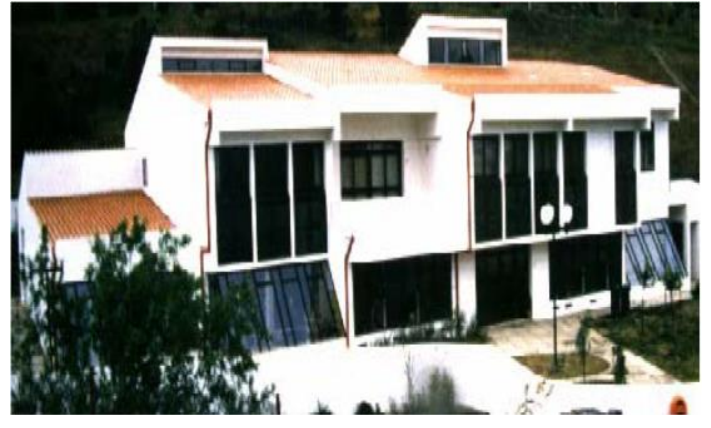

Figure 3. Nursery (Mertola)

Reference: Gonçalves et al., 1997 [7].

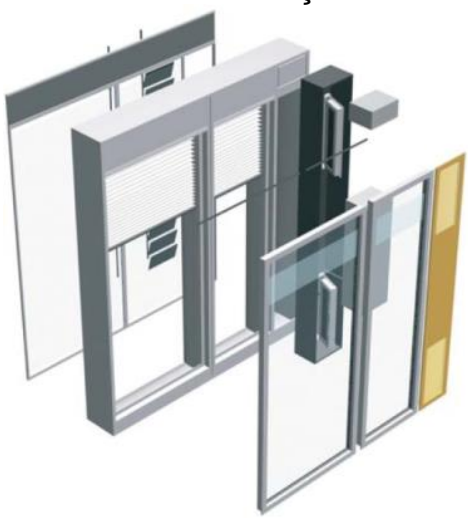

Figure 5. Temotion Façade. Reference: Productos y Referencias. Temotion, 2009 [15].

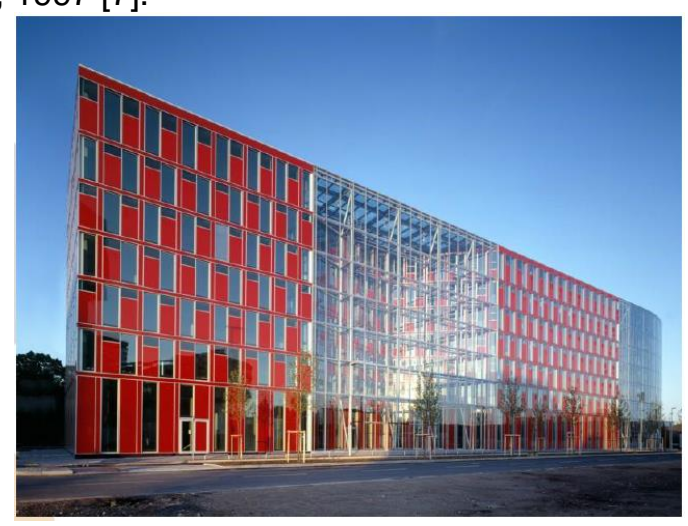

Figure 6. Capricorn Façade.

Reference: Treberspurg; Djalili (2010) [14]. 


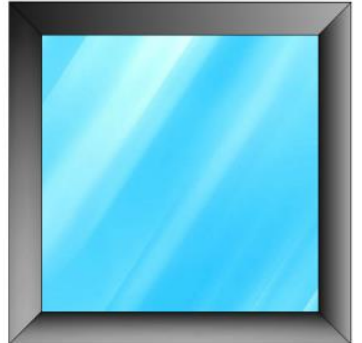

A. Standard fixed glazed module.

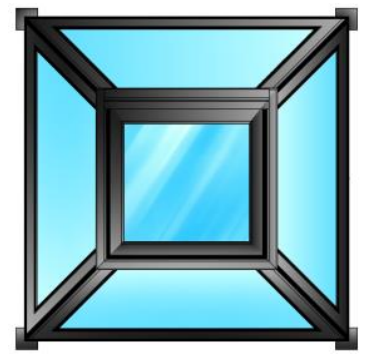

E. Sunspace module

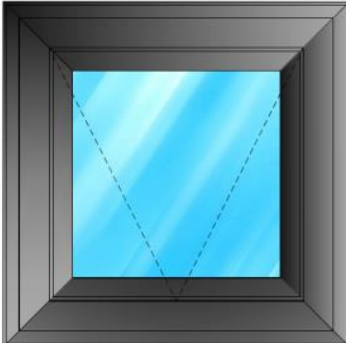

B. Standard awning glazed module.

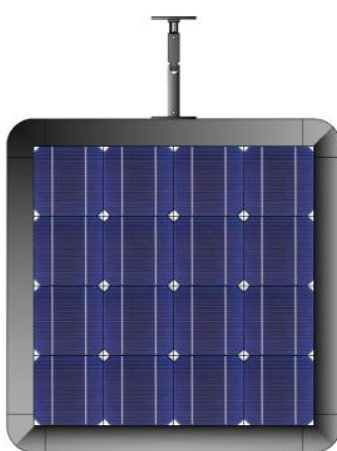

F. PV module.

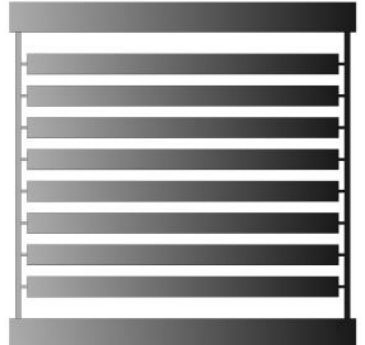

C. Sunshade module.

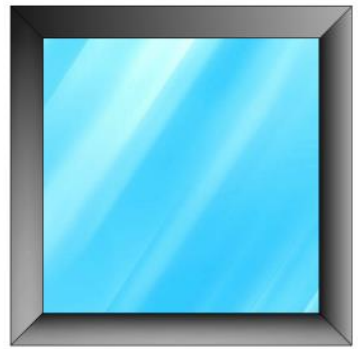

G. Trombe wall module.

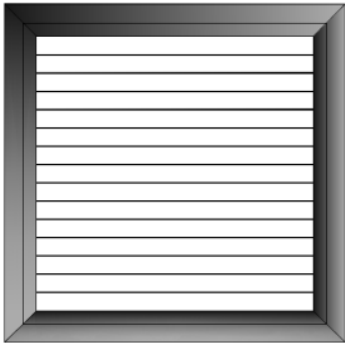

D. Ventilation module.

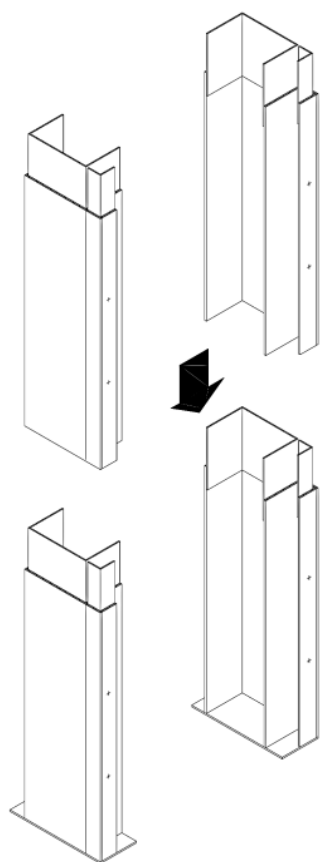

H Trombe wall support to massive walls.

Figure 7. Main idea of the modular façade system.

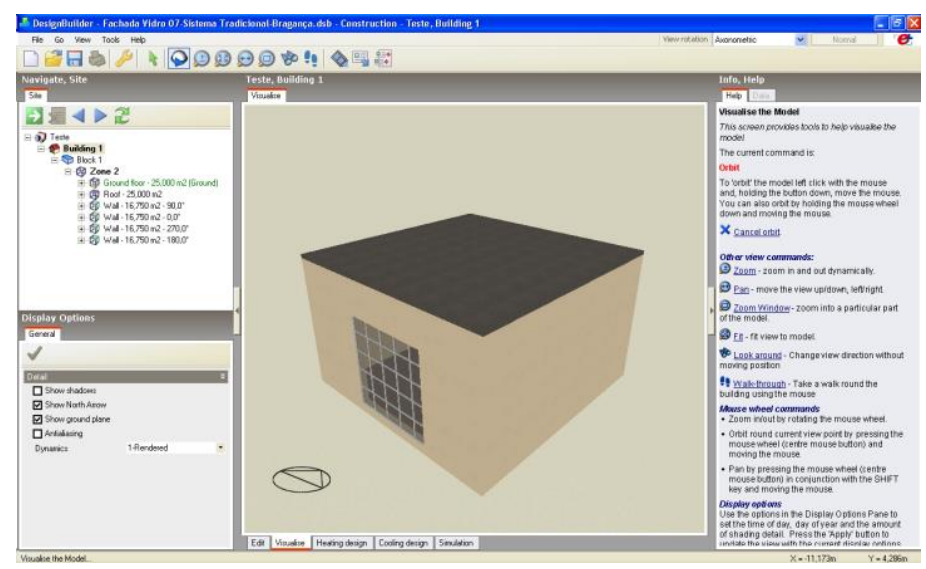

Figure 8. Main screen of DesignBuilder software. 


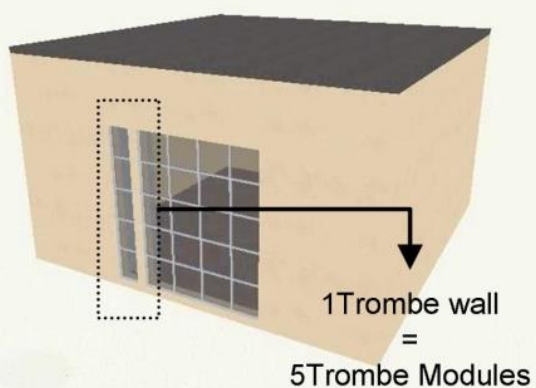

Figure 9. Model: One Trombe wall.

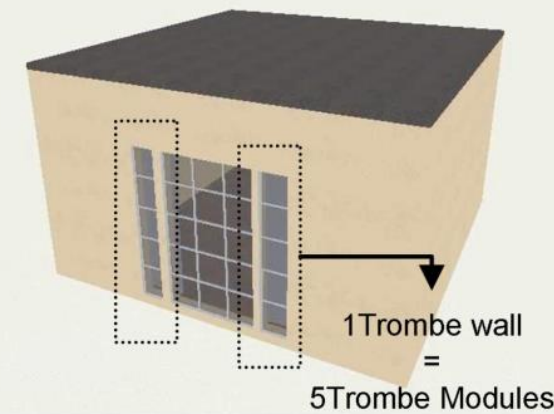

Figure 10. Model: Two Trombe walls.

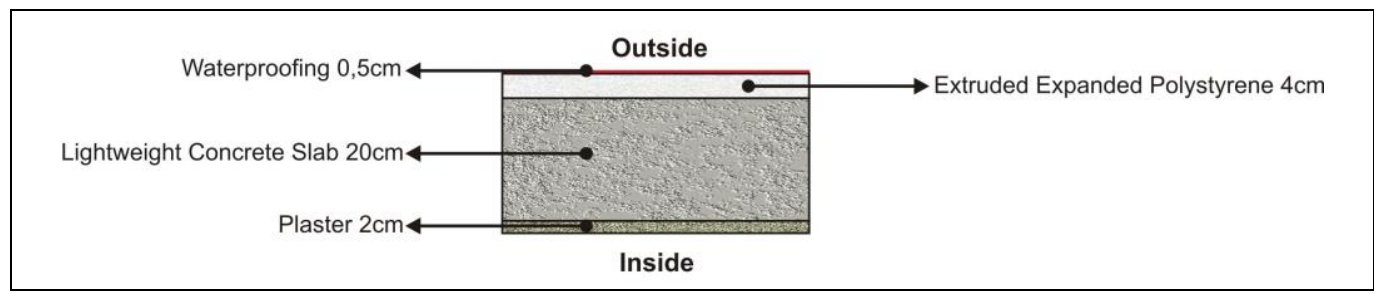

Figure 11. Portuguese Conventional System: Roof Slab.

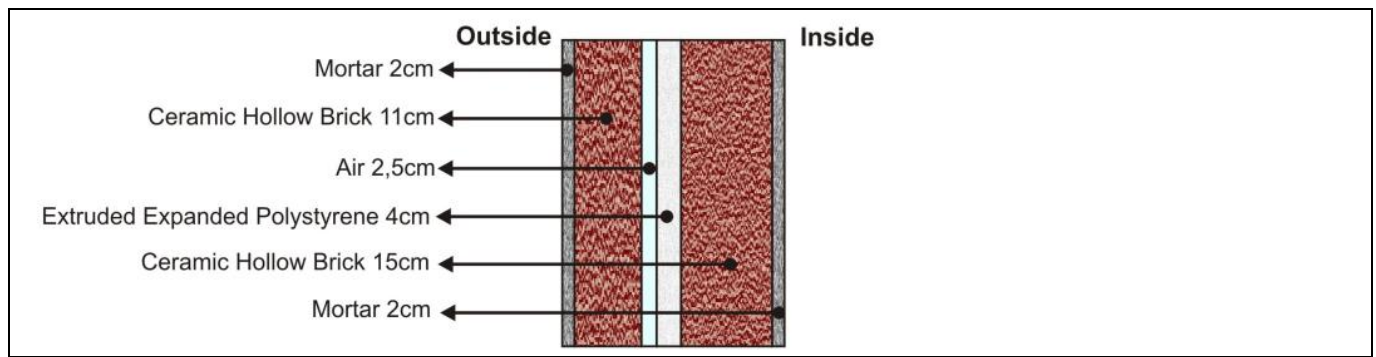

Figure 12. Portuguese Conventional System: Wall.

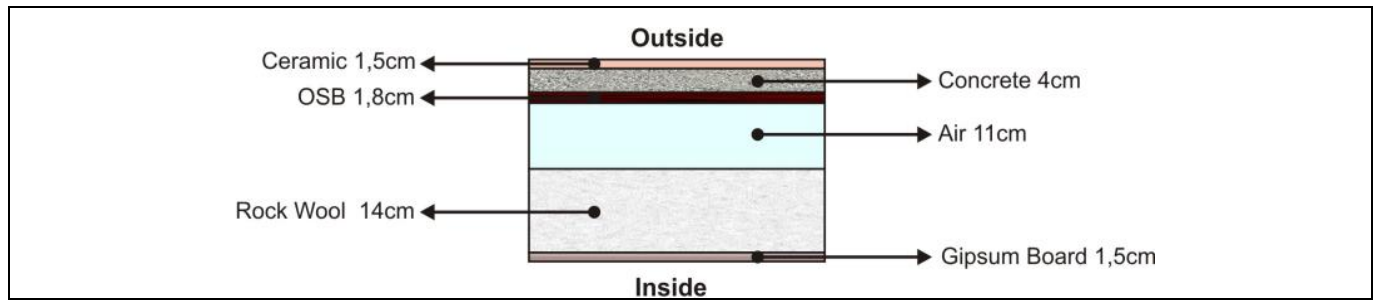

Figure 13. Light Gauge Steel Framing System: Roof Slab. 


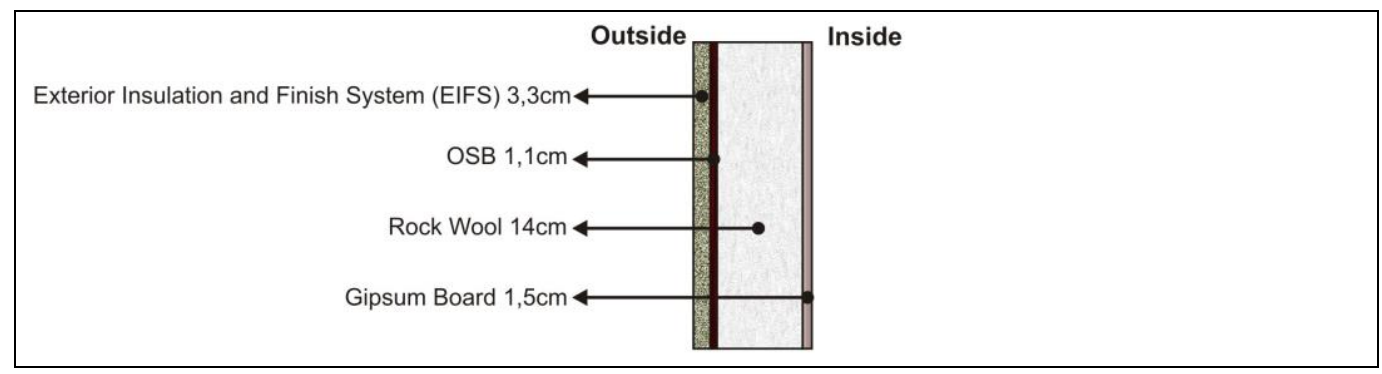

Figure 14. Light Gauge Steel Framing System: Wall.

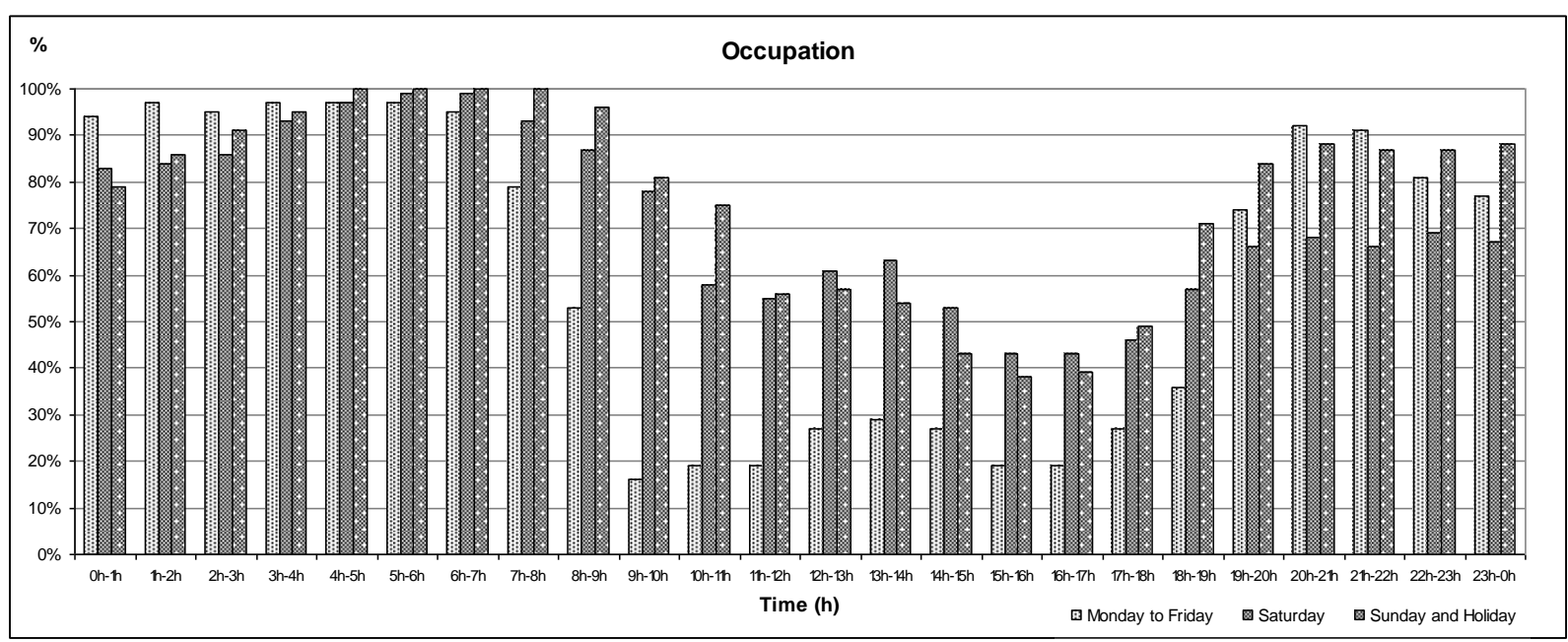

Figure 15. Occupation Schedule.

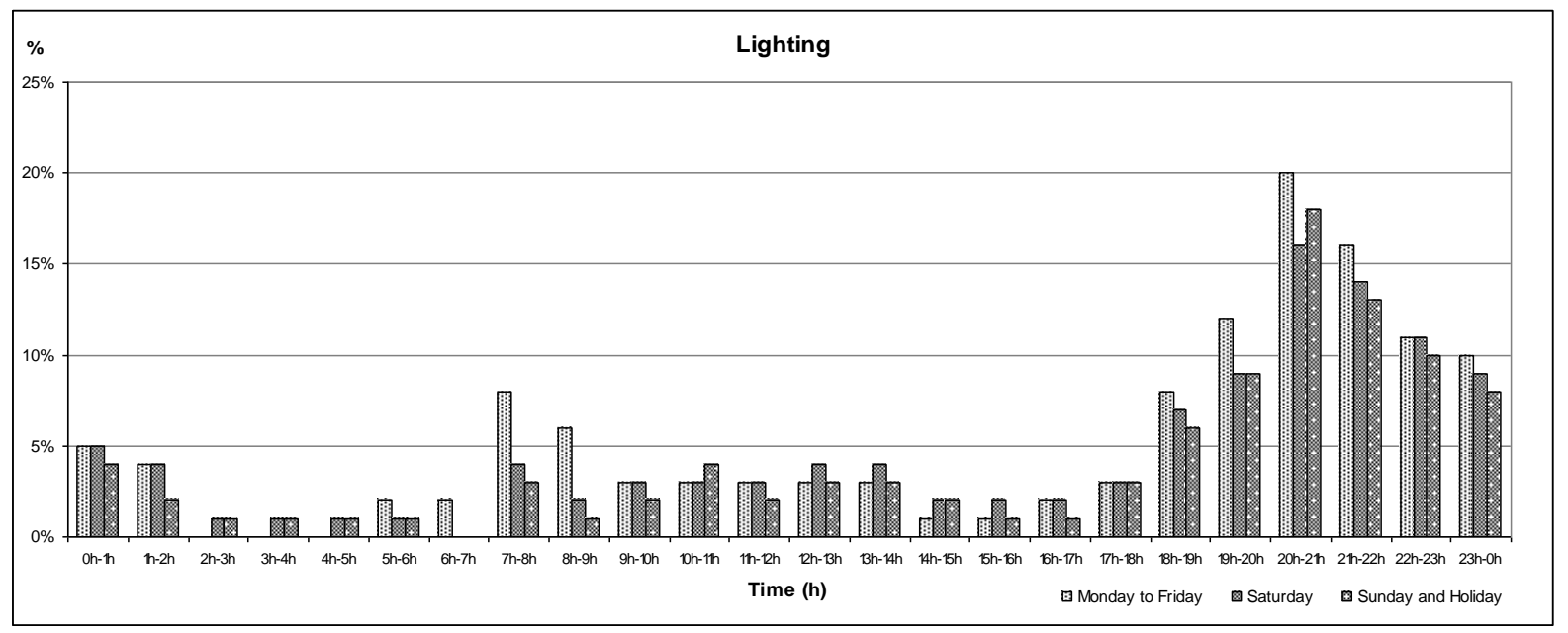

Figure 16. Lighting Schedule. 


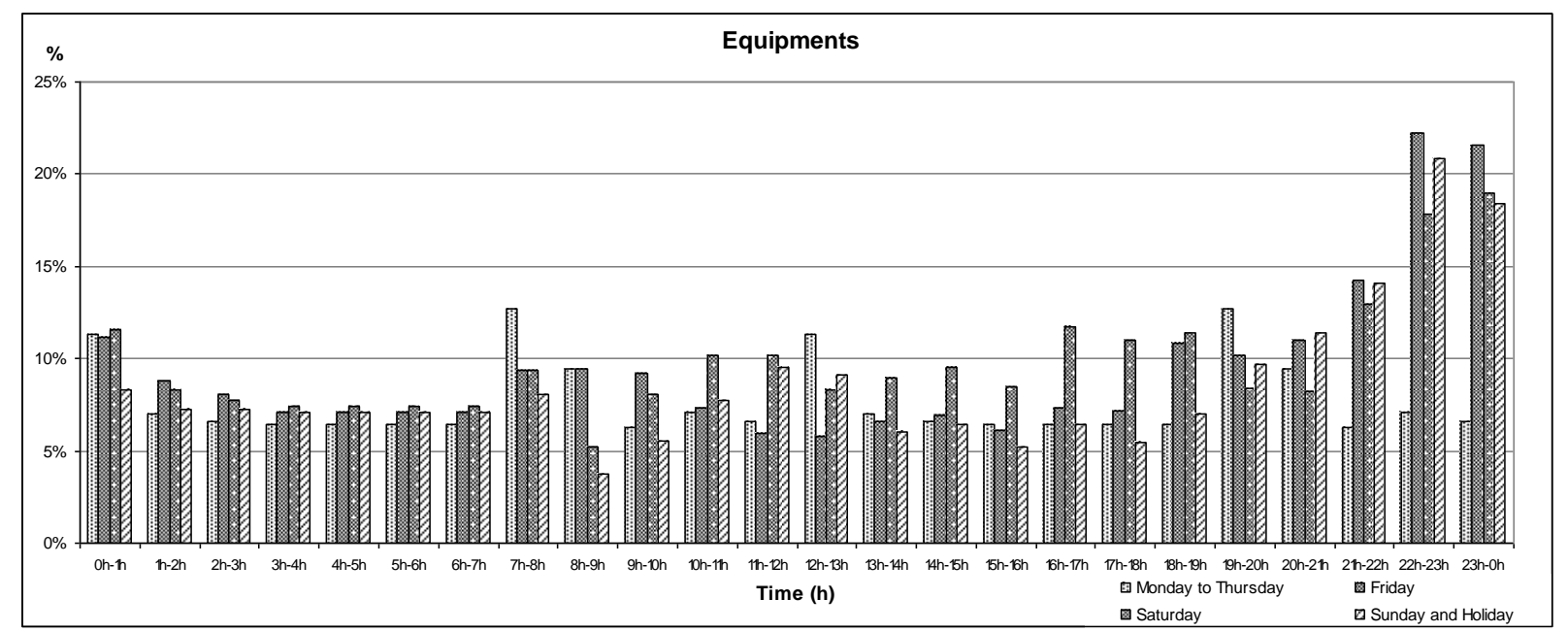

Figure 17. Equipment Schedule.

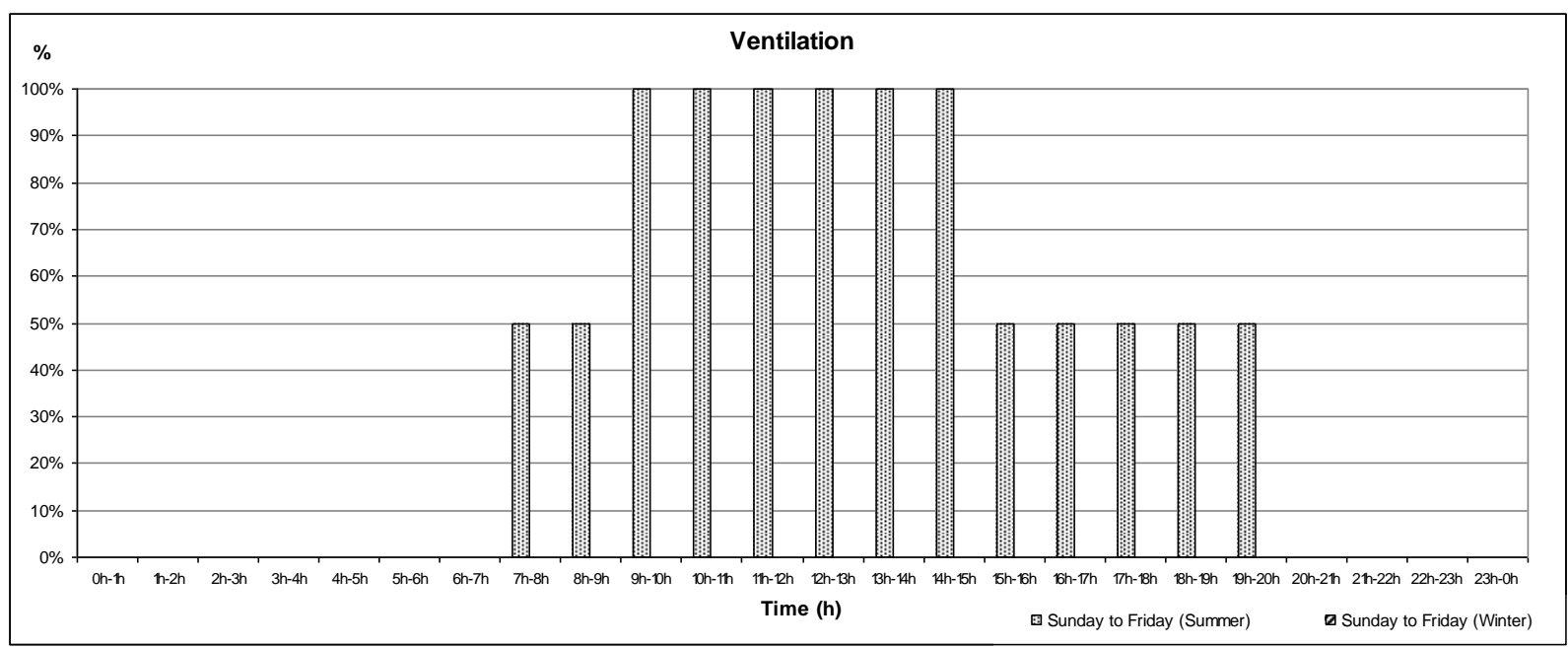

Figure 18. Ventilation Schedule.

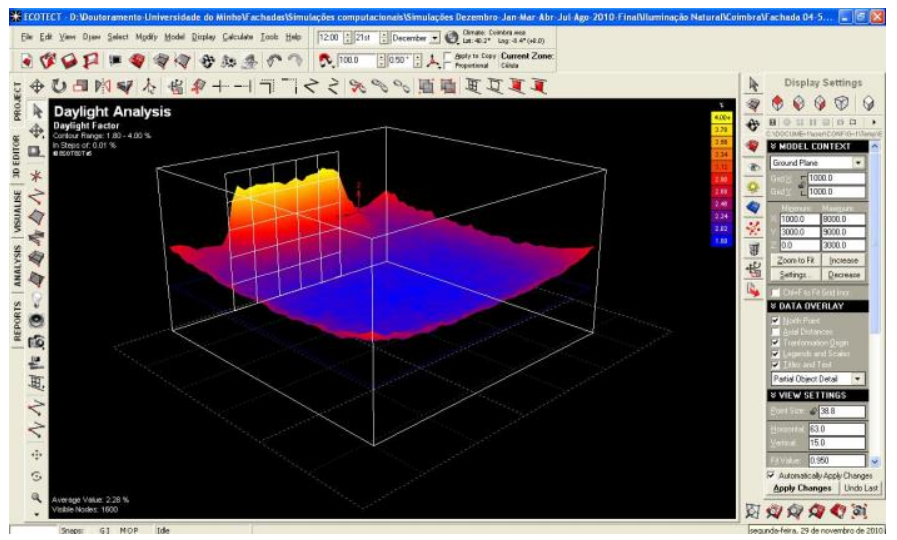

Figure 19. Ecotect Main Screen. 

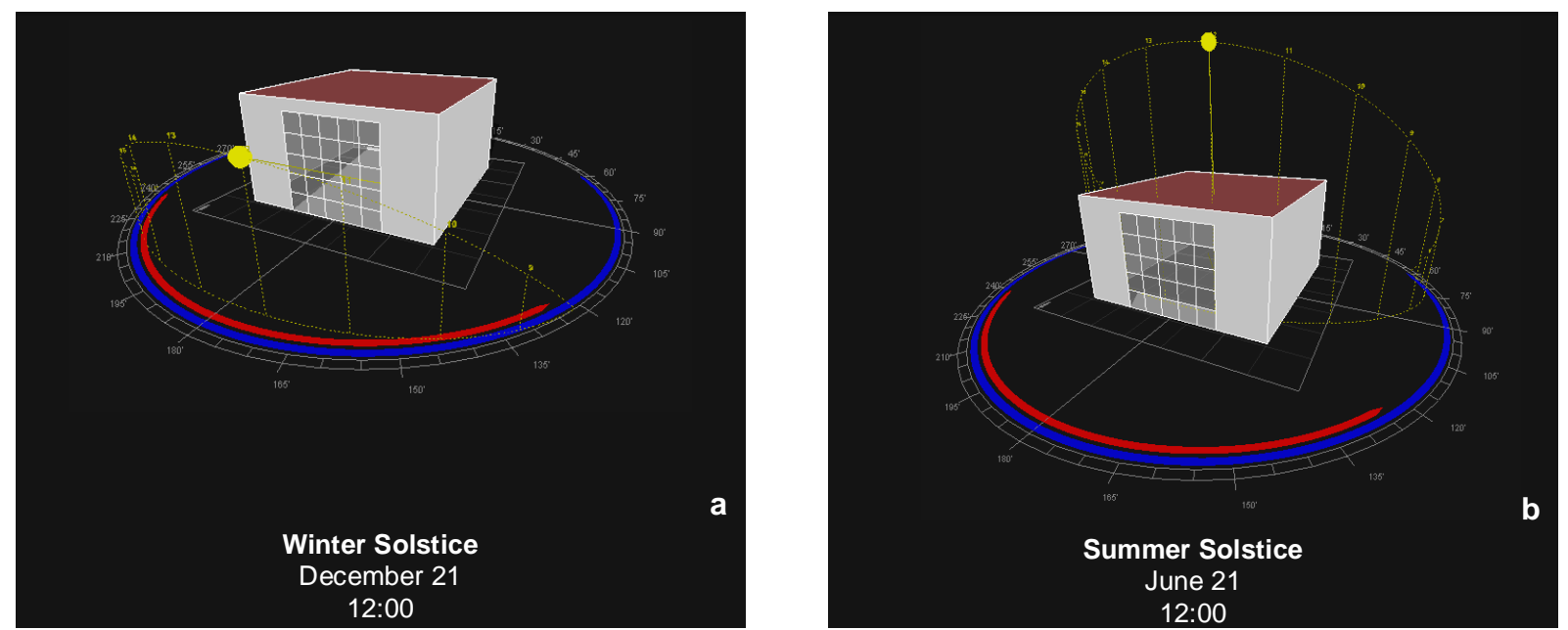

Figure 20. Conditions of Daylighting Simulation: 3D Illustrative diagrams (a) (b).
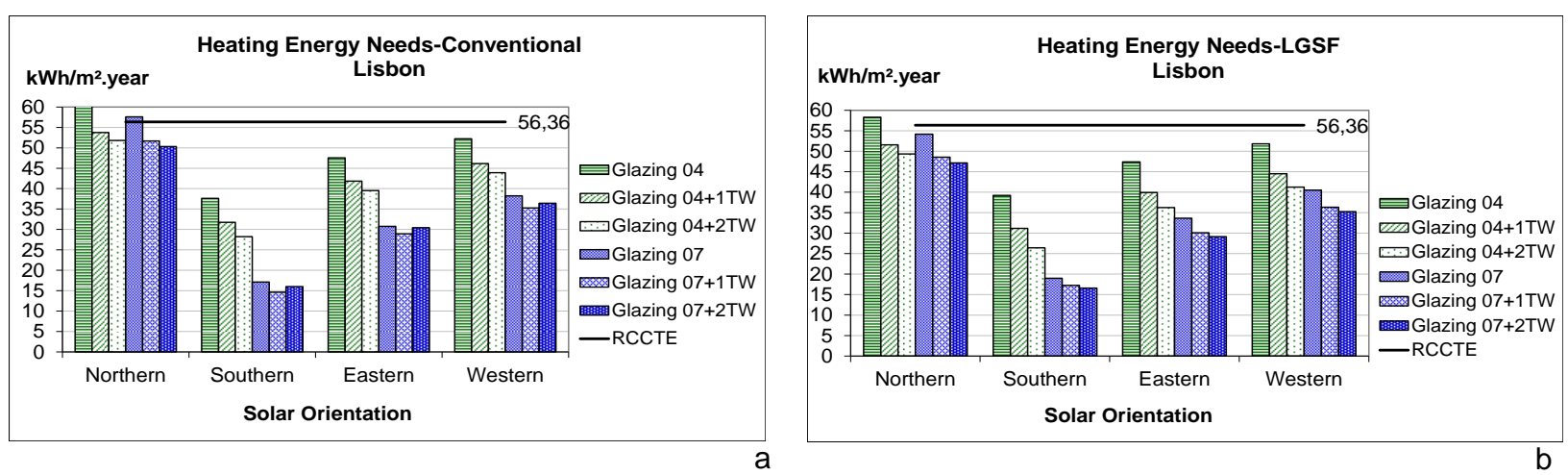

Figure 21. Lisbon: Heating Energy Needs. Conventional System (a) and LGSF System (b).
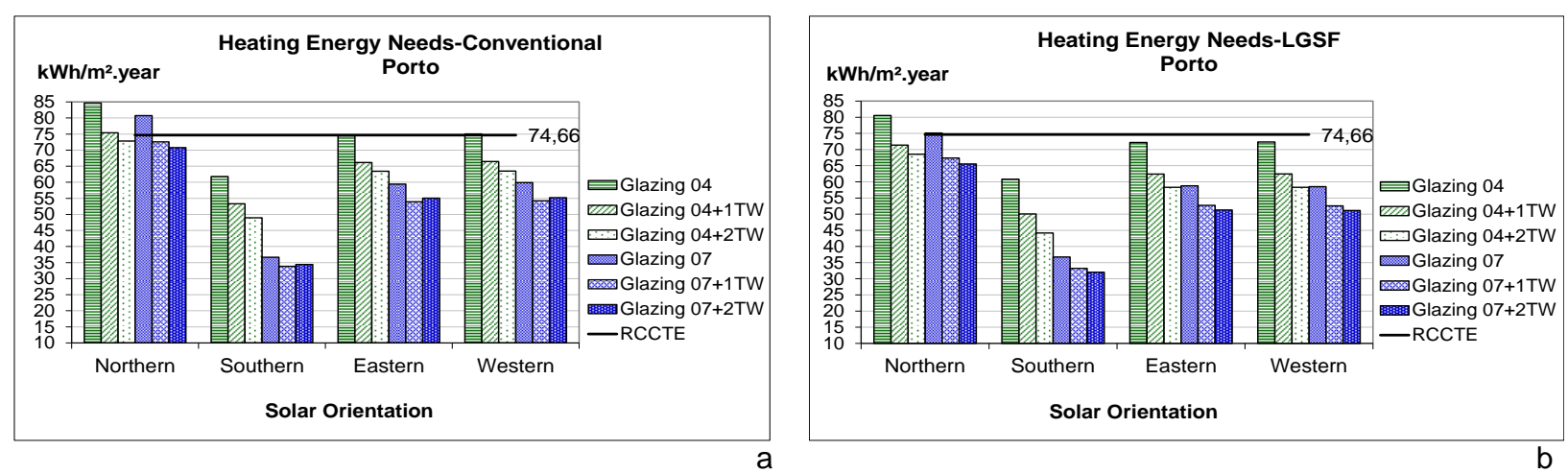

Figure 22. Oporto: Heating Energy Needs. Conventional System (a) and LGSF System (b). 

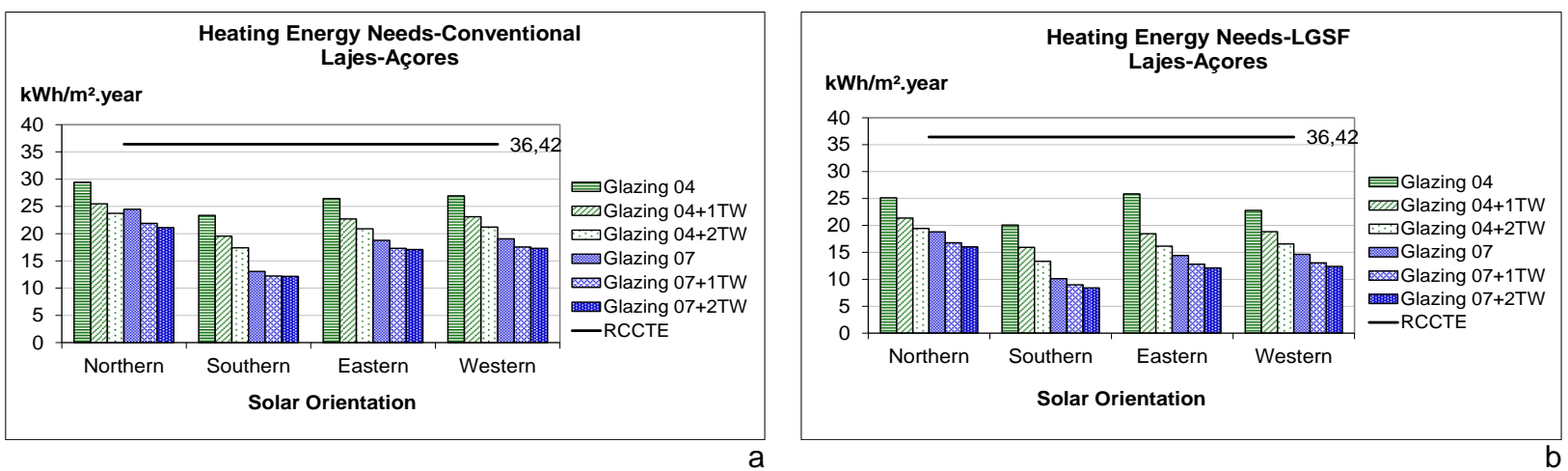

Figure 23. Lajes-Azores: Heating Energy Needs. Conventional System (a) and LGSF System (b).
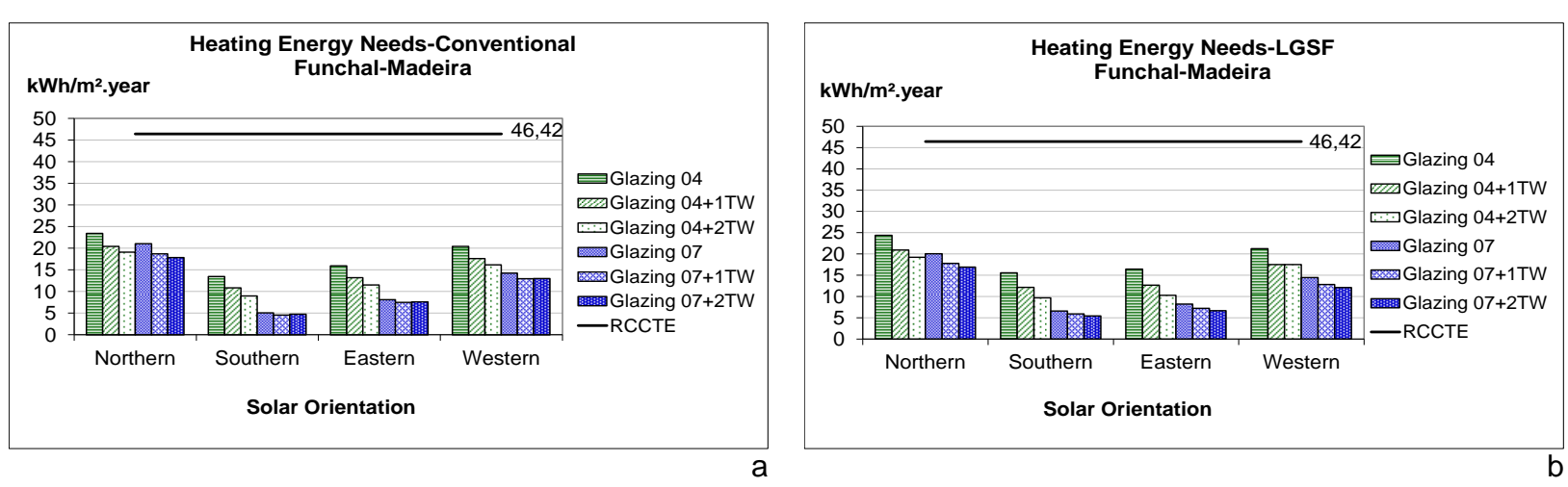

Figure 24. Funchal-Madeira: Heating Energy Needs. Conventional System (a) and LGSF System (b). 


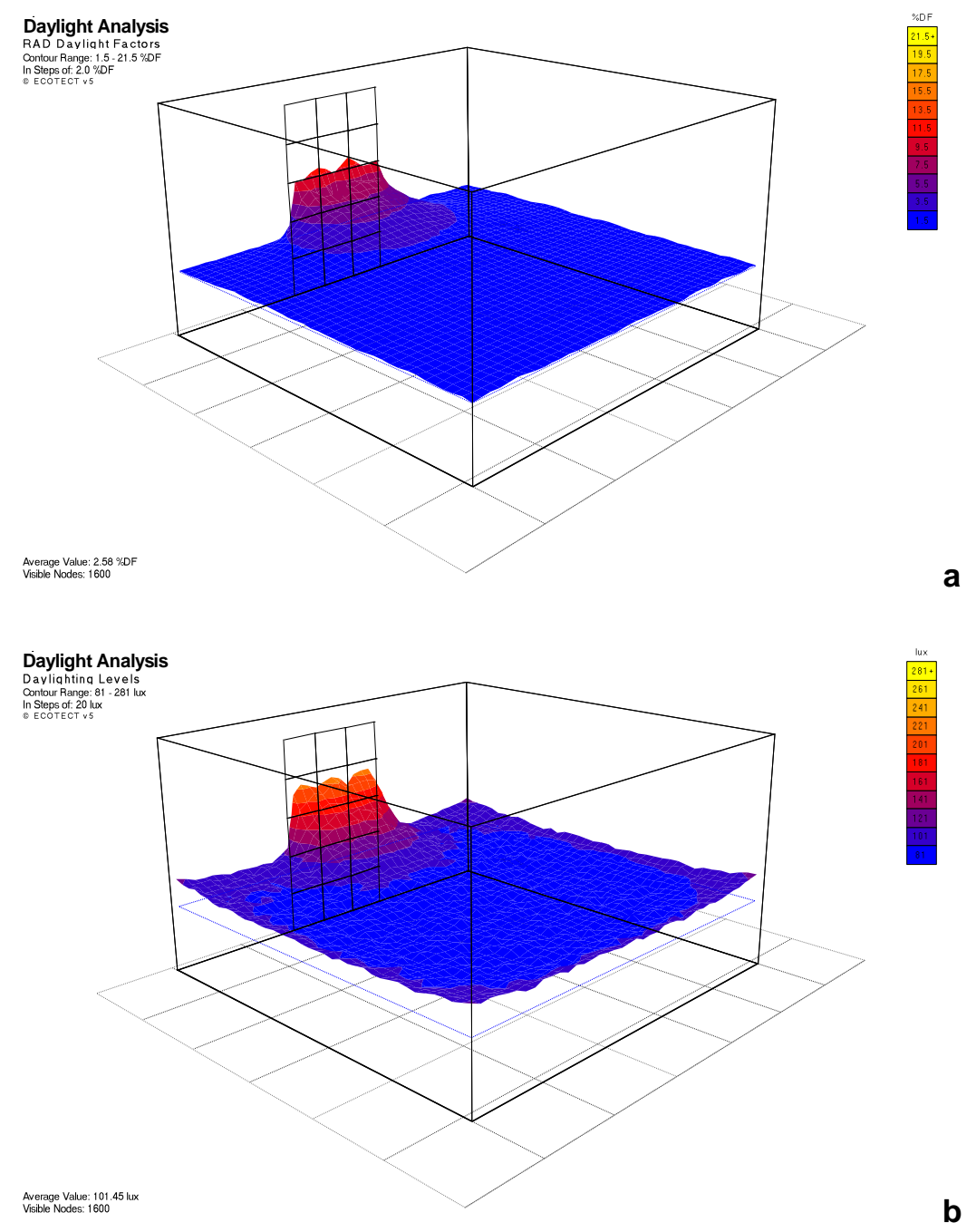

Figure 25. Lisbon - Glazing 04: Daylight Factor (a) and Illuminance Level (b). 


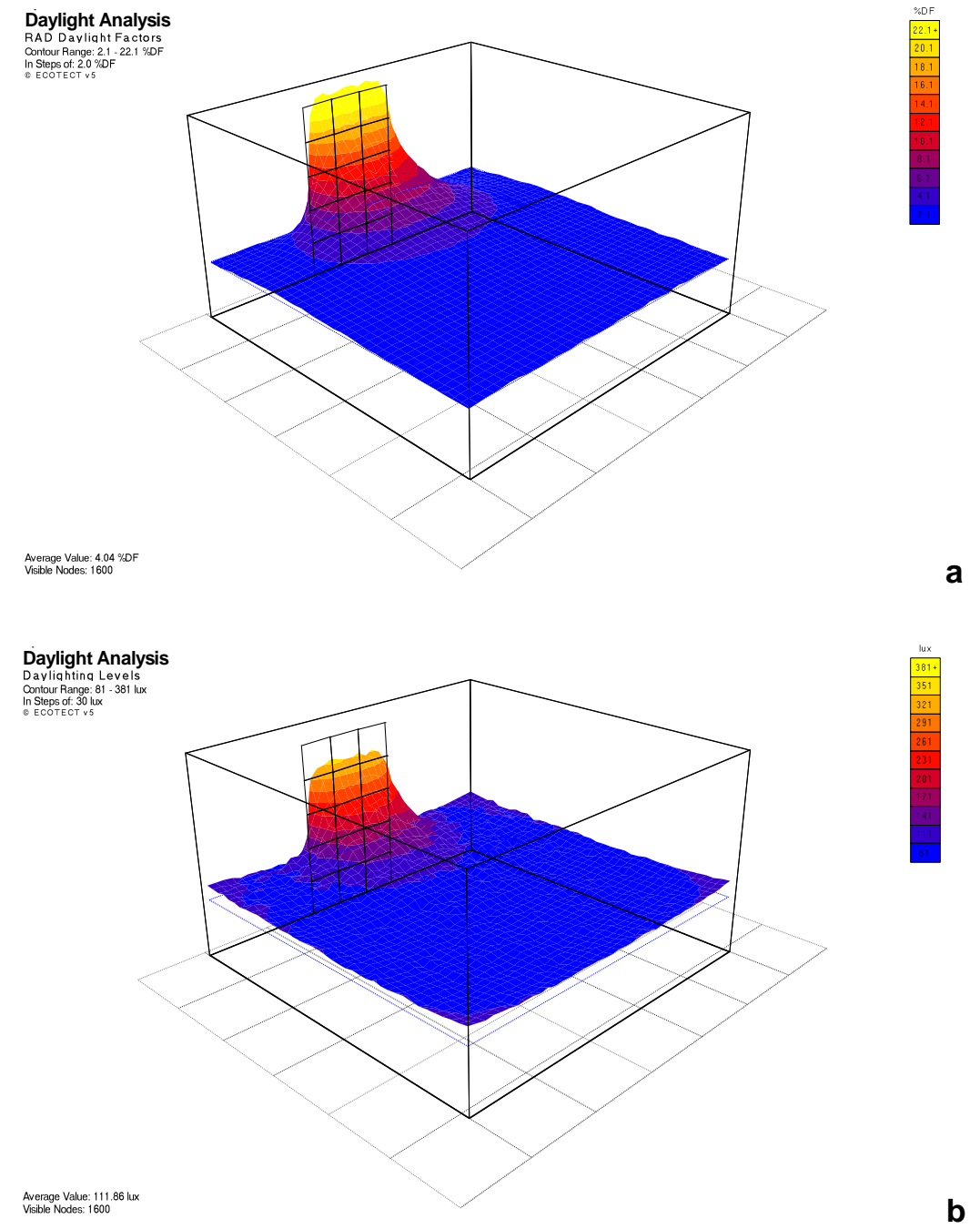

Figure 26. Lisbon - Glazing 07: Daylight Factor (a) and Illuminance Level (b). 


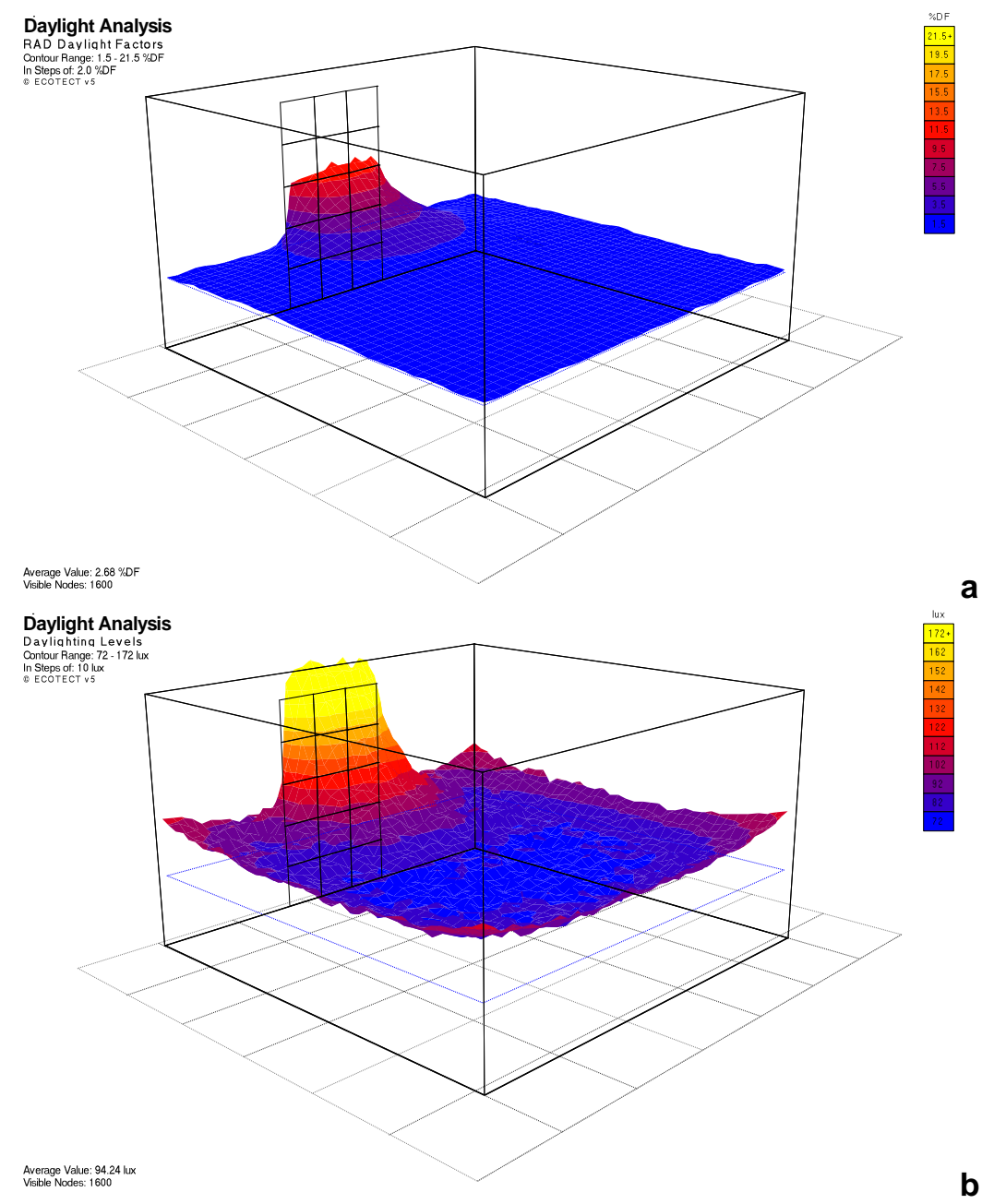

Figure 27. Oporto: Glazing 04 - Daylight Factor (a) and Illuminance Level(b). 


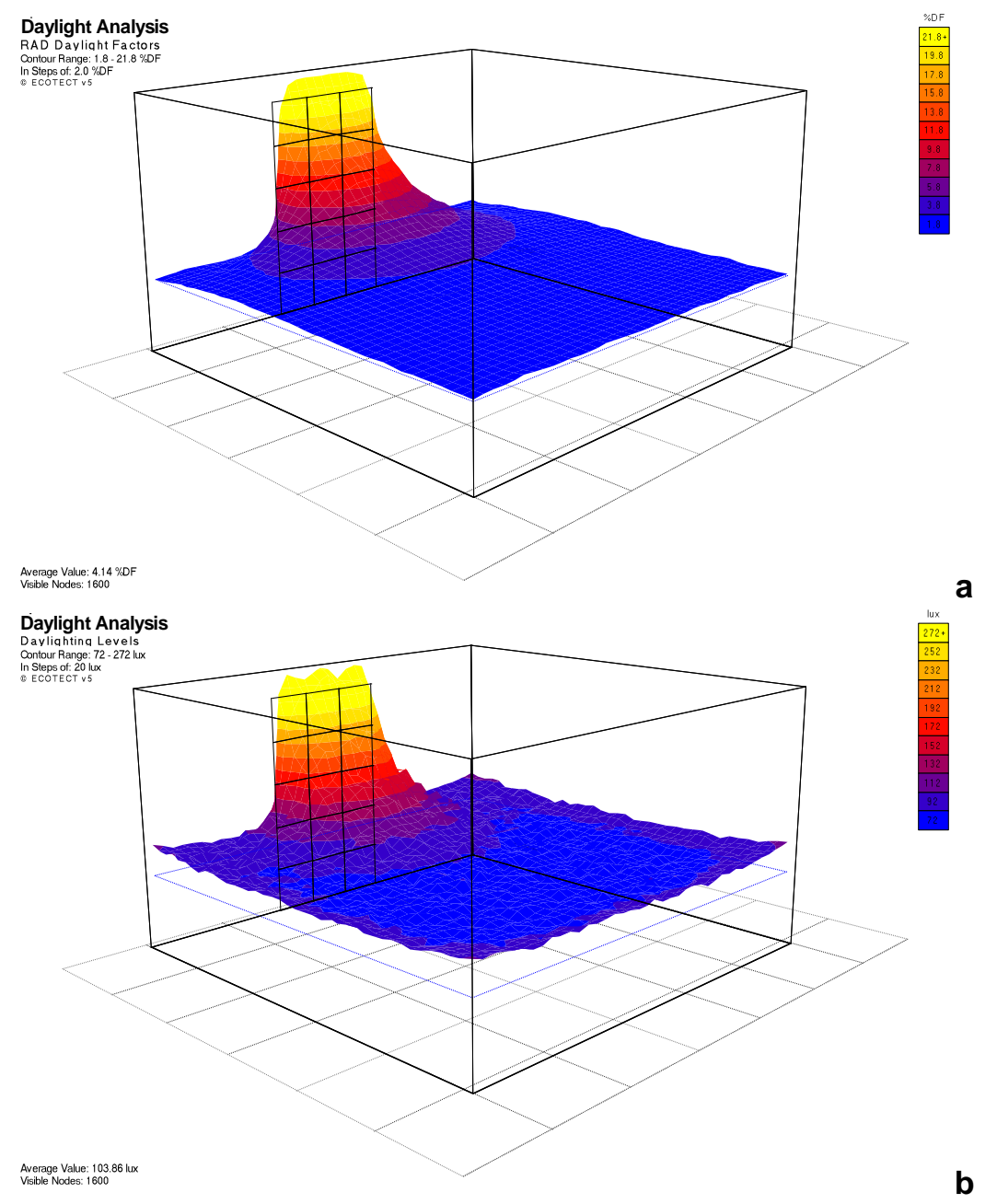

Figure 28. Oporto: Glazing 07 - Daylight Factor (a) and Illuminance Level(b). 


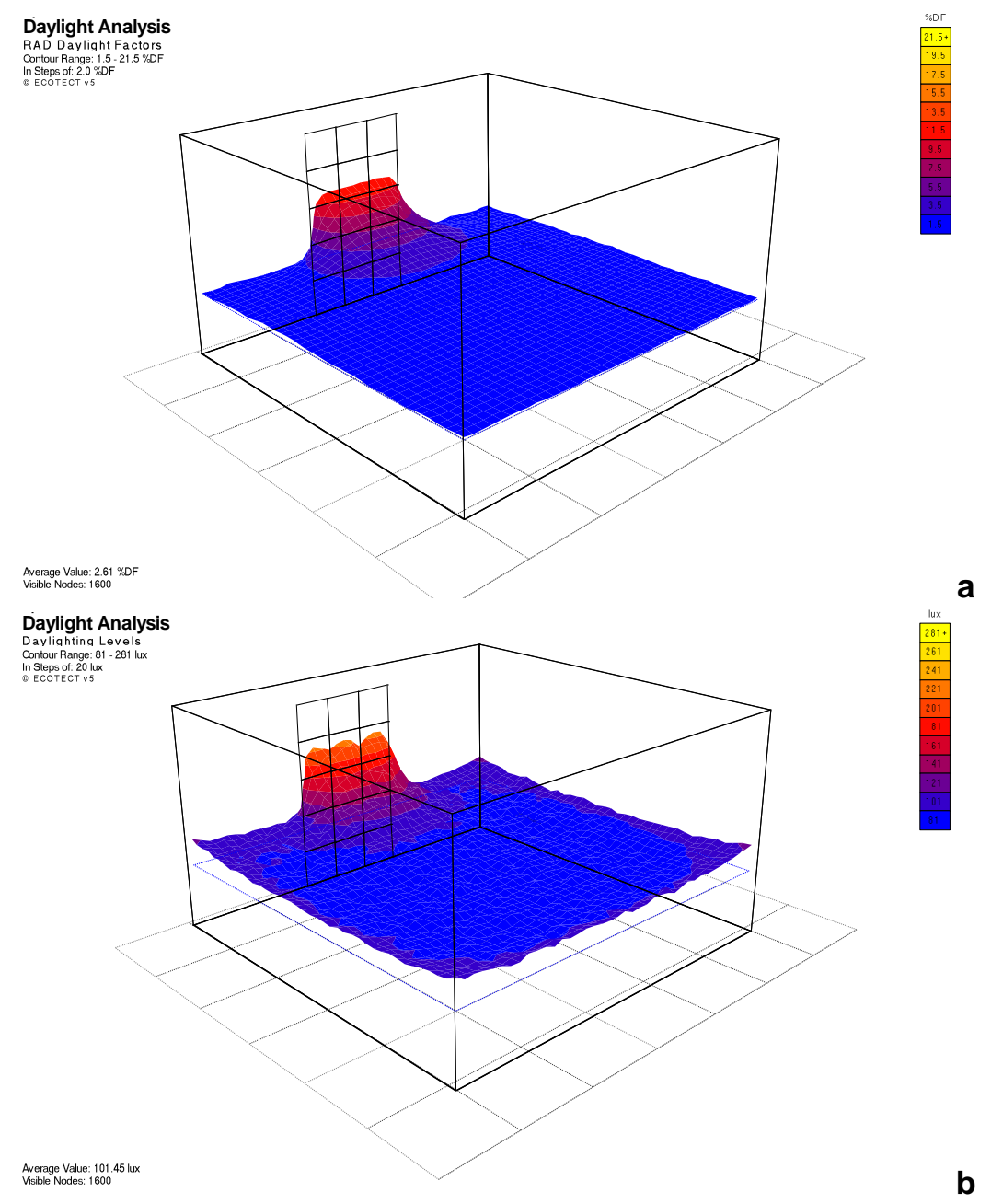

Figure 29. Lajes-Azores: Glazing 04 - Daylight Factor (a) and Illuminance Level(b). 


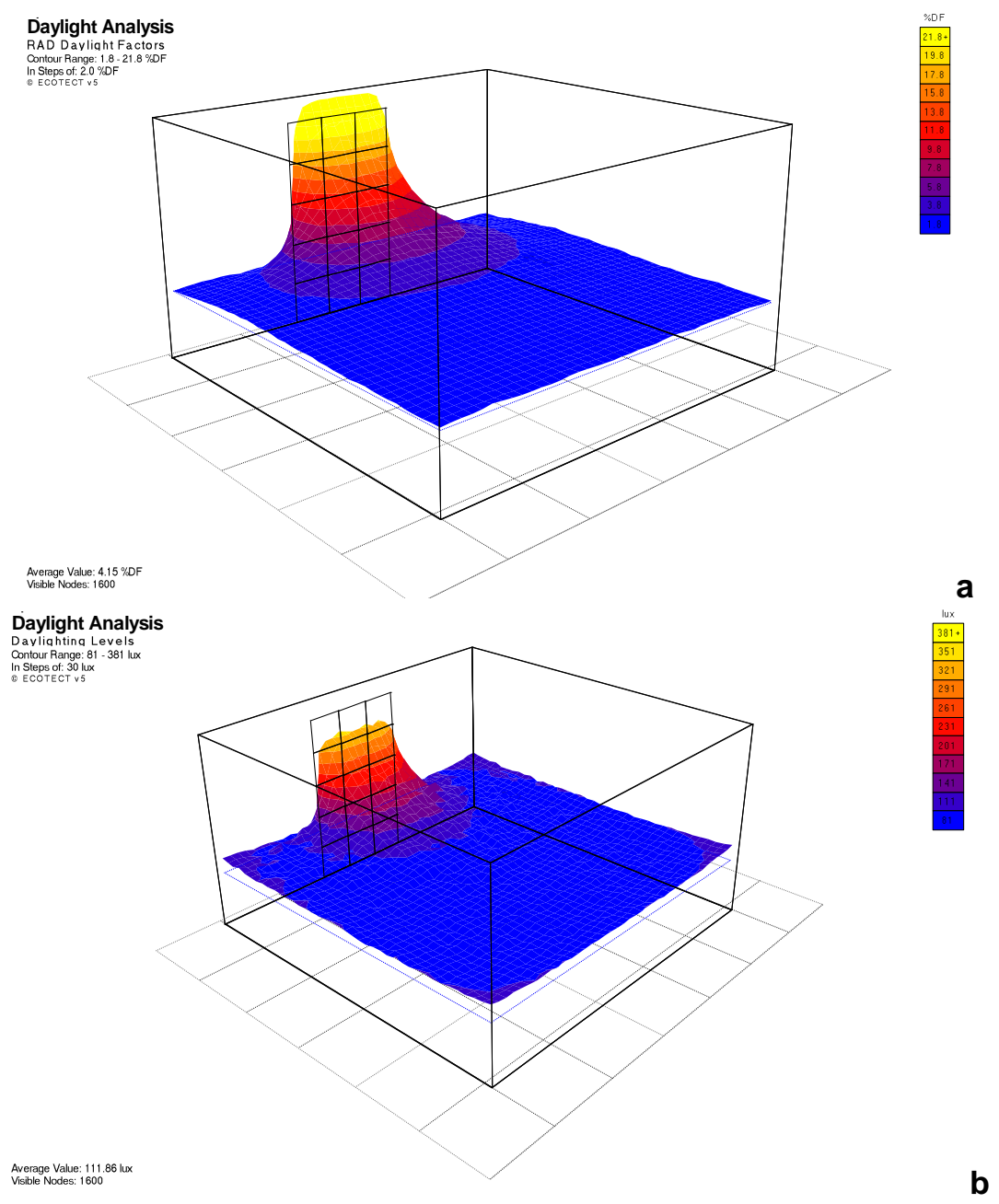

Figure 30. Lajes-Azores: Glazing 07 - Daylight Factor (a) and Illuminance Level(b). 


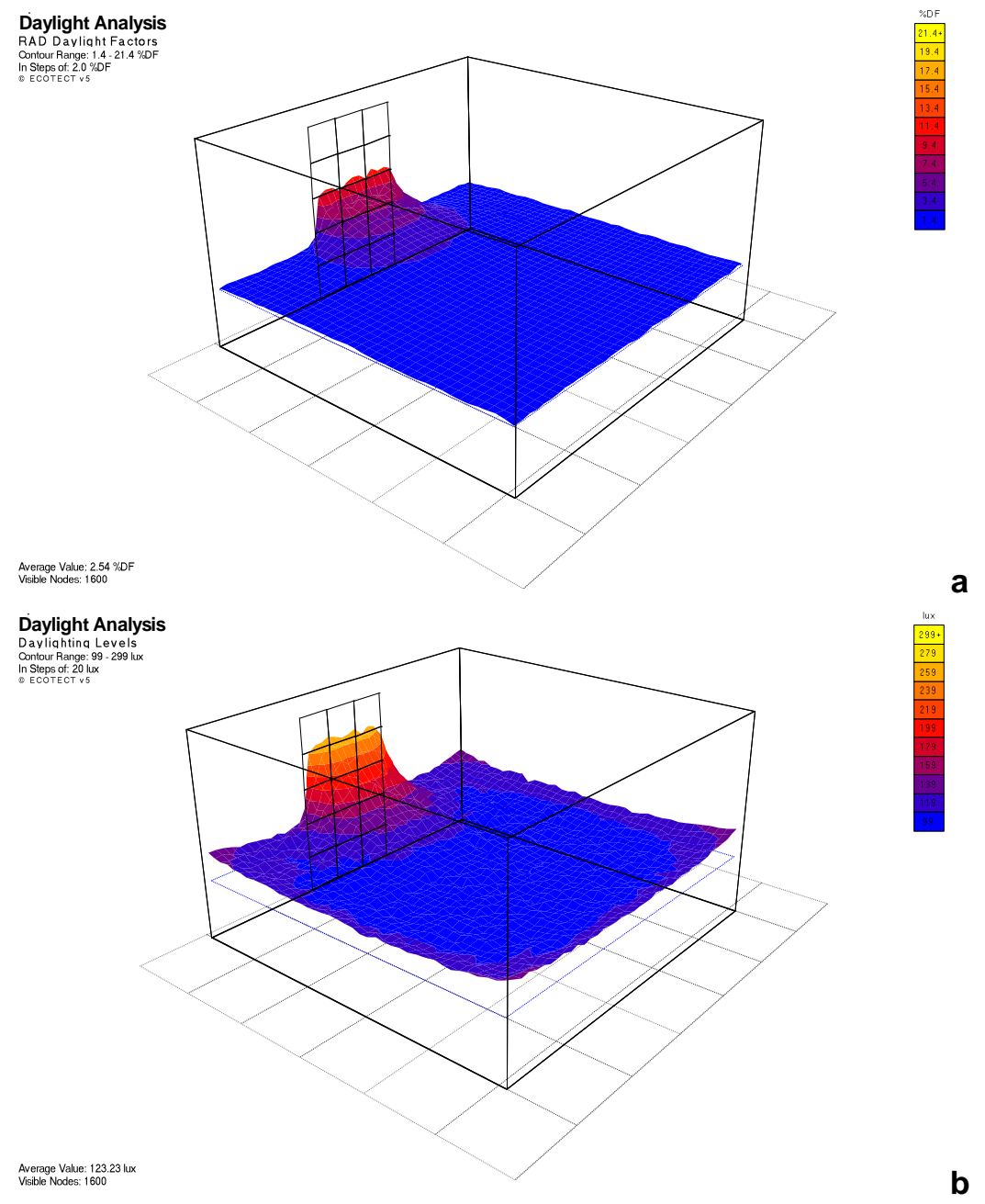

Figure 31. Funchal-Madeira: Glazing 04 - Daylight Factor (a) and Illuminance Level (b). 


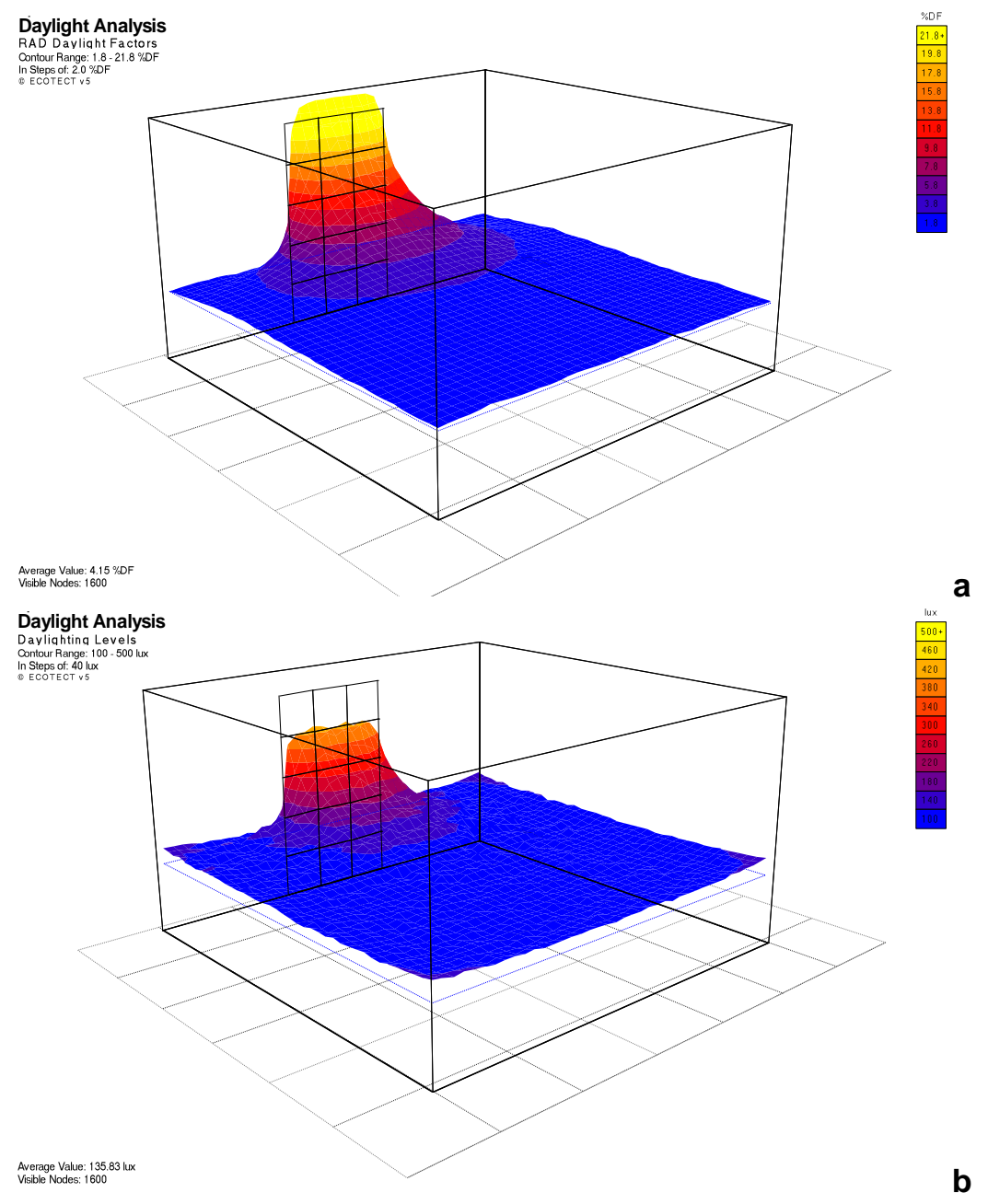

Figure 32. Funchal-Madeira: Glazing 07 - Daylight Factor (a) and Illuminance Level(b).

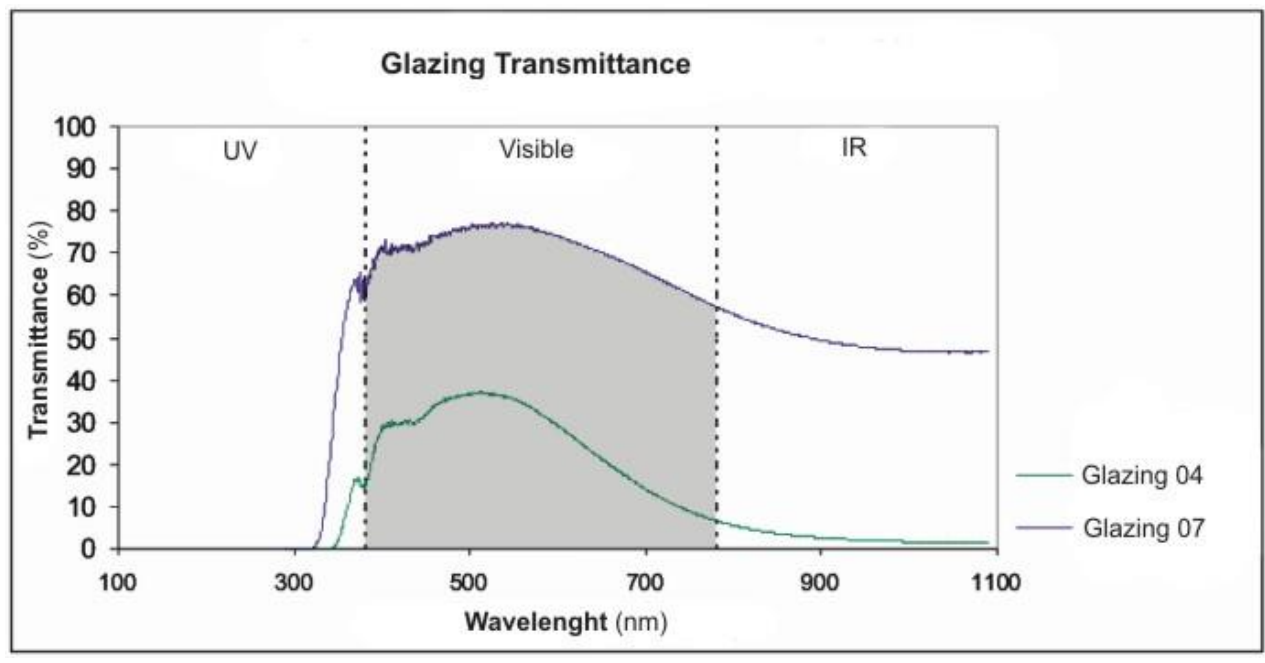

Figure 33. Glazing Transmittance Curves. 